\title{
Atmospheric dust modeling from meso to global scales with the online NMMB/BSC-Dust model - Part 2: Experimental campaigns in Northern Africa
}

\author{
K. Haustein ${ }^{1,2, *}$, C. Pérez ${ }^{3,4,5}$, J. M. Baldasano ${ }^{1,6}$, O. Jorba ${ }^{1}$, S. Basart ${ }^{1}$, R. L. Miller ${ }^{3,4}$, Z. Janjic , T. Black $^{7}$, \\ S. Nickovic ${ }^{8}$, M. C. Todd ${ }^{9}$, R. Washington ${ }^{2}$, D. Müller ${ }^{10,14,{ }^{* *}, \text { M. Tesche }}{ }^{11}$, B. Weinzierl ${ }^{12}$, M. Esselborn ${ }^{12,13}$, and \\ A. Schladitz ${ }^{14}$ \\ ${ }^{1}$ Barcelona Supercomputing Center, Earth Science Department, Barcelona, Spain \\ ${ }^{2}$ Climate Research Group, Centre for the Environment, University of Oxford, Oxford, UK \\ ${ }^{3}$ NASA Goddard Institute for Space Studies, New York, USA \\ ${ }^{4}$ Department of Applied Physics and Applied Math, Columbia University, New York, USA \\ ${ }^{5}$ International Research Institute for Climate and Society, Palisades, New York, USA \\ ${ }^{6}$ Environmental Modeling Laboratory, Technical University of Catalonia, Barcelona, Spain \\ ${ }^{7}$ Environmental Modeling Center, National Centers for Environmental Prediction, Camp Springs, Maryland, USA \\ ${ }^{8}$ Research Department, World Meteorological Organization, Geneva, Switzerland \\ ${ }^{9}$ Department of Geography, University of Sussex, Brighton, UK \\ ${ }^{10}$ School of Environmental Science and Engineering, Gwangju Institute of Science and Technology, Gwangju, South Korea \\ ${ }^{11}$ Department of Environmental Science, Stockholm University, Stockholm, Sweden \\ ${ }^{12}$ Deutsches Zentrum fur Luft- und Raumfahrt, Institut für Physik der Atmosphäre, Oberpfaffenhofen, Germany \\ ${ }^{13}$ European Southern Observatory, Technology Division, Garching, Germany \\ ${ }^{14}$ Leibniz Institute for Tropospheric Research, Leipzig, Germany \\ * now at: Climate Research Group, Centre for the Environment, University of Oxford, Oxford, UK \\ ** now at: Science Systems and Applications Inc., NASA Langley Research Center, Hampton, Virginia, USA
}

Correspondence to: K. Haustein (karsten.haustein@ouce.ox.ac.uk), C. Pérez (carlos.perezga@nasa.gov)

Received: 23 August 2011 - Published in Atmos. Chem. Phys. Discuss.: 9 November 2011

Revised: 12 March 2012 - Accepted: 13 March 2012 - Published: 23 March 2012

\begin{abstract}
The new NMMB/BSC-Dust model is intended to provide short to medium-range weather and dust forecasts from regional to global scales. It is an online model in which the dust aerosol dynamics and physics are solved at each model time step. The companion paper (Pérez et al., 2011) develops the dust model parameterizations and provides daily to annual evaluations of the model for its global and regional configurations. Modeled aerosol optical depth (AOD) was evaluated against AERONET Sun photometers over Northern Africa, Middle East and Europe with correlations around $0.6-0.7$ on average without dust data assimilation. In this paper we analyze in detail the behavior of the model using data from the Saharan Mineral dUst experiment (SAMUM-1) in 2006 and the Bodélé Dust Experiment (BoDEx) in 2005. AOD from satellites and Sun pho-
\end{abstract}

tometers, vertically resolved extinction coefficients from lidars and particle size distributions at the ground and in the troposphere are used, complemented by wind profile data and surface meteorological measurements. All simulations were performed at the regional scale for the Northern African domain at the expected operational horizontal resolution of $25 \mathrm{~km}$. Model results for SAMUM-1 generally show good agreement with satellite data over the most active Saharan dust sources. The model reproduces the AOD from Sun photometers close to sources and after long-range transport, and the dust size spectra at different height levels. At this resolution, the model is not able to reproduce a large haboob that occurred during the campaign. Some deficiencies are found concerning the vertical dust distribution related to the representation of the mixing height in the atmospheric 
part of the model. For the BoDEx episode, we found the diurnal temperature cycle to be strongly dependant on the soil moisture, which is underestimated in the NCEP analysis used for model initialization. The low level jet (LLJ) and the dust AOD over the Bodélé are well reproduced. The remaining negative AOD bias (due to underestimated surface wind speeds) can be substantially reduced by decreasing the threshold friction velocity in the model.

\section{Introduction}

Mineral dust emitted from arid and semi-arid areas is one of the most important sources of atmospheric aerosol mass and significantly impacts the Earth's climate system. Although there has been significant progress in estimating and modeling the dust cycle in the last decades, the magnitude of the dust net direct radiative forcing still remains uncertain varying between -0.56 and $+0.1 \mathrm{~W} \mathrm{~m}^{-2}$ (IPCC, 2007). Neither the annual global dust emission nor its spatial distribution is sufficiently well quantified, with the first to be in the range of 1000-2150 $\mathrm{Mt} \mathrm{yr}^{-1}$ (Zender et al., 2004; IPCC, 2007). Besides changing the global and regional energy balance by absorbing and scattering shortwave and longwave radiation (Houghton et al., 2001), dust transported by winds modifies atmospheric heating rates, temperatures and stability, influences the hydrological cycle (e.g. Sokolik and Toon, 1996; Tegen, 2003; Myhre et al., 2003; Miller et al., 2004; Helmert et al., 2007) and impacts human health (Yin et al., 2005), particularly close to source areas.

In the last few decades numerical models have been designed to reproduce the dust cycle allowing us to estimate the influence of mineral dust on the climate system. Dust models are also required for short to medium range air quality forecast applications. To this end, several models have been developed with some of them providing daily forecast products, e.g. the Dust REgional Atmospheric Model (DREAM) (Nickovic et al., 2001), the SKIRON model (Kallos et al., 1997), CHIMERE-Dust model (Menut et al., 2005), the Navy Aerosol Analysis and Prediction System (NAAPS) (Christensen, 1997), the JMA-MASINGAR dust model (Tanaka and Chiba, 2005), or the ECMWF-IFS (Morcrette et al., 2008). The DREAM model was further refined and tested in the last years. The updated version BSCDREAM8b (Pérez et al., 2006a,b, 2007; Papayannis et al., 2008; Haustein et al., 2009; Papanastasiou et al., 2010) is operated at the Barcelona Supercomputing Center-Centro Nacional de Supercomputación (BSC-CNS; http://www.bsc.es/ projects/earthscience/DREAM).

In the companion paper (Pérez et al., 2011), we described the NMMB/BSC-Dust, a new online multi-scale atmospheric dust model, designed and developed at the BSC in collaboration with NOAA/National Centers for Environmental Prediction (NCEP), NASA Goddard Institute for Space Stud- ies and the International Research Institute for Climate and Society (IRI). The dust model is embedded into the Nonhydrostatic Multiscale Model NMMB (Janjic et al., 2005; Janjic and Black, 2007; Janjic et al., 2011) and will provide short to medium-range dust forecasts for both regional and global domains. In Pérez et al. (2011), we evaluated monthly and annual means of the global configuration of the model against the AeroCom dust benchmark dataset for the year 2000 including surface concentration, deposition and aerosol optical depth (AOD), as well as the daily AOD variability in a regional domain at high resolution covering Northern Africa, Middle East and Europe against the AErosol RObotic NETwork (AERONET) (Holben et al., 1998) AOD for the year 2006. The NMMB/BSC-Dust provides us with a good description of the horizontal distribution and temporal variability of the dust. Daily AOD correlations at the regional scale were around $0.6-0.7$ on average without dust data assimilation. At the global scale the model lies within the top range of AeroCom dust models in terms of performance statistics for surface concentration, deposition and AOD.

In this contribution, we use the data from two field experiments: SAMUM-1 (Heintzenberg, 2009) and BoDEx (Washington et al., 2006a), complemented by in-situ remotesensing data and satellite retrievals to evaluate and analyze the behavior of the model in Northern Africa. The data from both campaigns have already been used for extensive model evaluation (e.g. Tegen et al., 2006; Bouet et al., 2007; Todd et al., 2007, 2008a; Haustein et al., 2009; Heinold et al., 2009; Müller et al., 2009; Otto et al., 2009, 2011). The first phase of SAMUM-1 took place in May/June 2006 at three sites in Morocco accompanied by overflights of two research aircraft as integral part of the campaign. The observational dataset includes ground-based (Raman and backscatter) and onboard High-Spectral-Resolution Lidar (HSRL) profiles, surface and tropospheric dust size distribution, aerosol mass concentration and chemical composition, dust sample microscopic and optical properties, Sun photometer data as well as basic meteorological parameters. The BoDEx experimental campaign took place in March 2005 at the Bodélé Depression (in the Djourab of northern Chad) which contributes well to over half of the annual dust that is produced in West Africa each year (Washington et al., 2003). Here, we mainly focus on the ability of the model to represent the local meteorology, notably the low-level jet feature (LLJ), and the dust emission pattern in this prolific dust source.

The paper is organized as follows. We summarize the model features presented in Pérez et al. (2011) in Sect. 2. In Sect. 3 we introduce the observational data from the two field campaigns and those derived from ground based and satellite remote sensing. Section 4 includes the results and discussion and we conclude in Sect. 5. 


\section{Model description}

\subsection{The NMMB/BSC-Dust model}

A detailed description of the model can be found in the companion paper (Pérez et al., 2011). This section summarizes the main characteristics of the NMMB/BSC-Dust model.

The NCEP-NMMB is the evolution of the NCEP/Eta (Janjic, 1990, 1994) and NCEP/WRF-NMME (Janjic et al., 2001; Janjic, 2003) with updated meteorological core, built on many decades of numerical weather prediction (NWP) experience. The model (Janjic and Black, 2006; Janjic et al., 2010, 2011) provides an improved numerical environment for the physical and dynamical schemes, essential to be able to increase the model resolution, the forecast domain or the number of incorporated physical and dynamical processes. The model is unified for regional and global simulations and has the non-hydrostatic option as add-on module (Janjic and Black, 2006; Janjic et al., 2010). In contrast to the WRF-NMME, it is now developed on the Arakawa B-grid (Arakawa and Lamb, 1977) with regular latitude-longitude coordinates for the global configuration and rotated latitudelongitude coordinates for the regional configuration. The Lorenz vertical staggered grid with pressure-sigma hybrid coordinate is used.

Dust is transported as the other tracers in the NMMB model. Tracer advection is Eulerian, positive-definite and monotonic. The Adams-Bashforth scheme is used for horizontal advection and the Crank-Nicholson scheme for vertical advection. For the horizontal diffusion the model uses a second order scheme. Dust emission and vertical diffusion, sedimentation, dry and wet deposition, and dust radiative feedback are also represented in the model. The default radiation scheme is the Geophysical Fluid Dynamics Laboratory (GFDL) package with longwave radiation after Fels and Schwarzkopf (1975) and shortwave radiation after Lacis and Hansen (1974). In order to take into account the effects of aerosols and mineral dust interactively, the rapid radiative transfer model (RRTM) (Mlawer et al., 1997) was implemented in the NMMB/BSC-Dust.

The dust emission scheme requires the calculation of the horizontal saltation and the vertical dust flux. It includes the threshold friction velocity $u_{* \text { thr }}$ which is the minimum friction velocity required to suspend soil particles in dependence of land surface conditions, surface wind speed and soil moisture (Bagnold, 1941; Iversen and White, 1982; Fécan et al., 1999). In this contribution we use the aeolian surface roughness over sand surfaces based on the roughness data set at $1 / 4^{\circ} \times 1 / 4^{\circ}$ spatial resolution provided by Laurent et al. (2008). The smooth surface roughness is calculated according to Marticorena and Bergametti (1995). For the saltation dust flux, the parameterization suggested in Marticorena and Bergametti (1995) with the horizontal flux formulation after White (1979) is used. Four parent soil size categories following Tegen et al. (2002) are taken into account (clay, silt, fine/medium sand, and coarse sand) covering a size range from $<2 \mu \mathrm{m}$ to $1000 \mu \mathrm{m}$. Soil mass fractions are calculated from the 12 top soil texture classes of the hybrid US General Soil Map-UN Food and Agriculture Organization (STATSGO-FAO) $1 \mathrm{~km}$ database (FAO-UNESCO, 1974).

The straight forward approach for the vertical flux after Marticorena and Bergametti (1995) is used, with and empirical horizontal-to-vertical-flux-ratio or sandblasting mass efficiency $\alpha$. For sources we use the topographic preferential source approach after Ginoux et al. (2001) and the National Environmental Satellite, Data, and Information Service (NESDIS) vegetation fraction climatology (Ignatov and Gutman, 1998). The vertical dust flux is distributed over three log-normal size modes by means of a standard error function reflecting the observed background aerosol distribution over source regions (D'Almeida, 1987; Zender et al., 2003b). These 3 bins are re-distributed over 8 transport model size bins with effective radii of $0.15,0.25,0.45,0.78$, $1.3,2.2,3.8,7.1 \mu \mathrm{m}$.

The dust dry deposition is based on Zhang et al. (2001) and includes simplified empirical parameterizations for the deposition processes of Brownian diffusion, impaction, interception and gravitational settling detailed in Slinn (1982).

Wet scavenging of dust by precipitation is computed separately for convective and grid-scale precipitation. The model includes parameterizations for in-cloud and sub-cloud scavenging. The standard cloud and precipitation schemes of the NMMB model are the grid-scale cloud microphysical scheme of Ferrier et al. (2002), and the convective adjustment scheme of Betts-Miller-Janjic (BMJ) (Betts, 1986; Betts and Miller, 1986; Janjic, 1994). For moist convective mixing it is assumed that dust is mixed vertically analogously to moisture, so that the reference vertical profile for dust preserves similarity to that of moisture in the BMJ approach.

\subsection{Model set-up}

We performed regional simulations in a model domain covering Northern Africa, the Arabian Peninsula and southern/central Europe ( 0 to $65^{\circ} \mathrm{N}$ and $25^{\circ} \mathrm{W}$ to $60^{\circ} \mathrm{E}$ ) as schematically illustrated in Fig. 1 . The model resolution was set to $1 / 4^{\circ} \times 1 / 4^{\circ}$ (about $25 \mathrm{~km}$ ) with 40 vertical layers for all simulations which is expected to be the regional forecast model resolution. The model meteorology was reinitialized every $24 \mathrm{~h}$ and the boundary conditions updated every $6 \mathrm{~h}$ with global NCEP final analysis (FNL) data at $1^{\circ} \times 1^{\circ}$ resolution. A seven-day dust spin-up was performed for each simulation. For the BoDEx period, we performed additional simulations using soil moisture initial conditions from the Global Land Data Assimilation System (GLDAS) (Rodell et al., 2004).

The model backscatter coefficient is derived directly from the extinction coefficient, applying an empirical extinctionto-backscatter or lidar (LR) ratio. The LR is rather variable and depends strongly on size, shape and complex refractive 


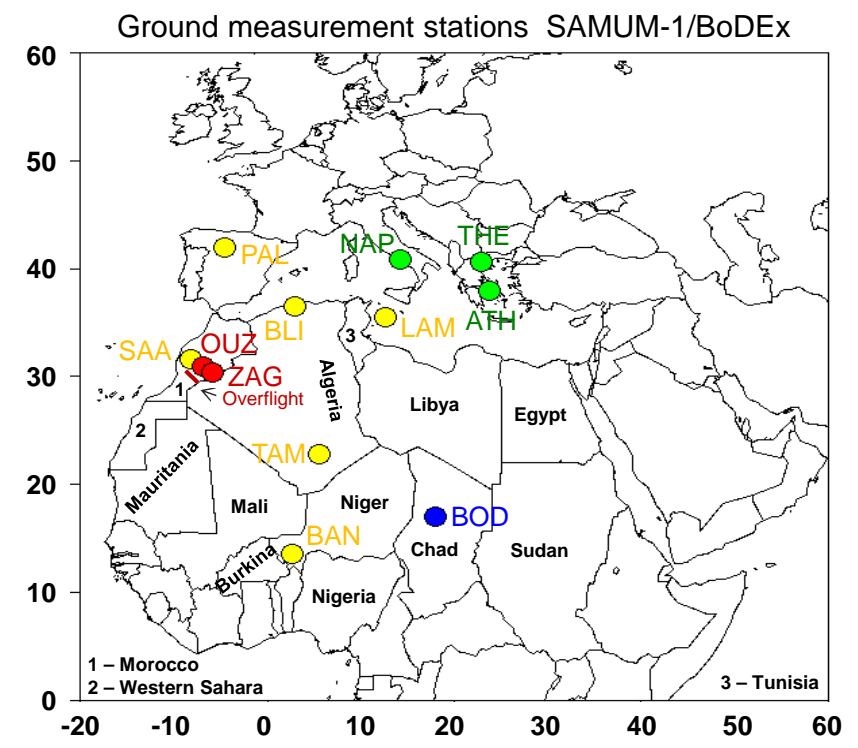

Fig. 1. Overview of all ground measurement stations within the model simulation domain used in this paper. Red dots are the SAMUM-1 field sites Ouarzazate (OUZ) and Zagora (ZAG), yellow dots are AERONET stations, the blue dot is the BoDEx field site Chicha, and the green spots are EARLINET lidar stations. The Falcon overflight path just south of Ouarzazate and Zagora is shown in red.

index of the particle (Mishchenko et al., 1997). We use a constant LR of 50 sr suggested by Papayannis et al. (2008) after conducting a statistical analysis of dust events with data from the European Aerosol Research LIdar NETwork (EARLINET) (Bösenberg et al., 2003). This is in good agreement with the mean LR of $54.8 \pm 6.7 \mathrm{sr}$ at $532 \mathrm{~nm}$ found during SAMUM-1 (Tesche et al., 2009). The model number size distribution is diagnosed at the corresponding height levels and is derived assuming sphericity and average dust particle density of $2.6 \mathrm{~g} \mathrm{~cm}^{-3}$ (Hess et al., 1998).

\section{Observational data}

This section provides a brief introduction of the two field experiments and describes the available observational in-situ and remote sensing products. In Fig. 1, the red dots refer to the SAMUM-1 field sites at Ouarzazate Airport and Zagora and the green and yellow dots indicate the AERONET and EARLINET stations complementary used here for the same period. The region where the Falcon overflight took place on 19 and 20 May 2006 is indicated with the red line. The blue dot refers to the BoDEx field campaign site at Chicha in the Bodélé Depression. The respective station names, acronyms and locations are given in Table 1.
Table 1. Location of all AERONET and EARLINET stations including the BoDEx station Chicha in the Bodélé Depression.

\begin{tabular}{llrrr}
\hline Acron. & Location & Altitude & Latitude & Longitude \\
\hline PAL & Palencia & $743 \mathrm{~m}$ & $41.99^{\circ} \mathrm{N}$ & $4.51^{\circ} \mathrm{W}$ \\
SAA & Saada & $1890 \mathrm{~m}$ & $31.63^{\circ} \mathrm{N}$ & $8.16^{\circ} \mathrm{W}$ \\
OUZ & Ouarzazate & $1133 \mathrm{~m}$ & $30.94^{\circ} \mathrm{N}$ & $6.91^{\circ} \mathrm{W}$ \\
ZAG & Zagora & $730 \mathrm{~m}$ & $30.33^{\circ} \mathrm{N}$ & $5.84^{\circ} \mathrm{W}$ \\
BLI & Blida & $230 \mathrm{~m}$ & $36.51^{\circ} \mathrm{N}$ & $2.88^{\circ} \mathrm{E}$ \\
LAM & Lampedusa & $50 \mathrm{~m}$ & $35.52^{\circ} \mathrm{N}$ & $12.63^{\circ} \mathrm{E}$ \\
TMR & Tamanrasset & $1400 \mathrm{~m}$ & $22.79^{\circ} \mathrm{N}$ & $5.53^{\circ} \mathrm{E}$ \\
BAN & Banizoumbou & $250 \mathrm{~m}$ & $13.54^{\circ} \mathrm{N}$ & $2.66^{\circ} \mathrm{E}$ \\
BOD & Chicha & $179 \mathrm{~m}$ & $17.0^{\circ} \mathrm{N}$ & $18.0^{\circ} \mathrm{E}$ \\
NAP & Naples & $118 \mathrm{~m}$ & $40.84^{\circ} \mathrm{N}$ & $14.18^{\circ} \mathrm{E}$ \\
THE & Thessaloniki & $60 \mathrm{~m}$ & $40.63^{\circ} \mathrm{N}$ & $22.95^{\circ} \mathrm{E}$ \\
ATH & Athens & $200 \mathrm{~m}$ & $37.96^{\circ} \mathrm{N}$ & $23.78^{\circ} \mathrm{E}$ \\
\hline
\end{tabular}

\subsection{SAMUM-1 field experiment}

SAMUM-1 took place from 11 May to 10 June 2006 in southern Morocco, around Ouarzazate (1133 m a.s.l.), Tinfou (720 m a.s.l.) and Zagora (situated $150 \mathrm{~km}$ southeast of Ouarzazate and next to Tinfou), accompanied by overflights of two research aircraft.

In this study, we use profiles of the $532 \mathrm{~nm}$ extinction coefficient from the six-wavelength aerosol lidar Backscatter Extinction lidar-Ratio Temperature Humidity profiling Apparatus (BERTHA) at Ouarzazate (Althausen et al., 2000; Tesche et al., 2009). Profiles are available for heights between 1$7 \mathrm{~km}$ and the lidar data have a temporal resolution of $30 \mathrm{~s}$ and a vertical resolution of $60 \mathrm{~m}$. The profiles shown in this work are averaged over one to three hours (Tesche et al., 2009). The airborne measurements taken aboard the Falcon aircraft of the German Aerospace Center (DLR) combined HSRL (Esselborn et al., 2009) at $532 \mathrm{~nm}$ with a variety of in-situ instruments (Weinzierl et al., 2009) to probe the atmosphere in the Ouarzazate area between $0-11 \mathrm{~km}$ height. The surface size distribution was quasi-continuously measured by means of a combination of a Differential Mobility Particle Sizer (DMPS) and an Aerodynamic Particle Sizer (APS). The mobility or aerodynamic size range was between $20 \mathrm{~nm}$ and $5 \mu \mathrm{m}$ diameter, respectively (Schladitz et al., 2009). Large particles between $4-500 \mu \mathrm{m}$ were collected by two different impactor types applying the method of impactor collection on coated glass substrates once every day (Kandler et al., 2009; Schladitz et al., 2009).

The upper level vertical aerosol size distribution was derived on constant altitude sequences outside of clouds aboard the Falcon aircraft over the Ouarzazate region (same flight as for lidar measurements). It carried instrumentation for measuring dust particle size distributions in the size range of $4 \mathrm{~nm}$ to $100 \mu \mathrm{m}$ diameter using Condensation Particle Counters (CPCs) and several Optical Particle Counters (OPCs). 
Particles larger than $30 \mu \mathrm{m}$ were present in $\sim 50 \%$ of the cases (Esselborn et al., 2009; Weinzierl et al., 2009).

\subsection{BoDEx field experiment}

BoDEx took place from 28 February to 13 March 2005 and represents the first and unique field study in the Bodélé Depression, which lies between the Tibesti Mountains and Lake Chad in Mali. The observation site Chicha was located at the eastern margin of the large diatomite deposit, originating from the paleo-lake Mega-Chad. It is known to be one of the global key source areas for mineral dust (Prospero et al., 2002; Washington et al., 2003), exhibiting a pronounced dust emission hot spot (Giles, 2005; Todd et al., 2007).

Time-height profiles of wind speed and direction were derived from PIlot BALloon (PIBAL) ascents (Devara et al., 1998; Egger et al., 2005). Nine ascents were made per day with higher sampling frequency in the morning so that the effects of surface heating on the wind field could be best resolved. The single theodolite method was used, with heights calculated from the balloon's buoyancy prior to release and balloon elevation and azimuths recorded at minute intervals. Wind speed and direction was averaged over 2 min intervals so that the effect of turbulent eddies could be minimized. Typical daytime tracks lasted $35 \mathrm{~min}$ and typical nighttime tracks lasted $18 \mathrm{~min}$. Wind field with PIBALs could not be sampled in case of extreme dust events and too low visibility (Washington et al., 2006a). AOD was measured at the Chicha ground station by means of CIMEL Sun photometer. Also $2 \mathrm{~m}$ temperature was measured at Chicha (Todd et al., 2008a,b).

\subsection{Satellite remote sensing products and data}

To qualitatively compare the spatio-temporal distribution of the modeled extinction AOD, satellite based remote sensing retrievals are used. The MSG infrared dust index is an RGB (Red, Green, Blue) composite image based upon infrared channel satellite data providing the dust aerosol information by means of a pink colored contrast image. It is computed from the brightness temperature differences of three SEVIRI channels (IR 8.7, 10.8, 12.0) and is designed to monitor the evolution of dust storms and hence a useful tool to identify dust sources both at day and night (Schmetz et al., 2002). For example, a dust source activation frequency map was derived (Schepanski et al., 2007) and analyzed regarding the sub-daily distribution as a function of meteorological processes (Schepanski et al., 2009). Complementary, we use the NASA's SeaWiFS instrument that provides visible dust images (Hooker et al., 1992). It has been used in some studies to identify the dust transport (e.g. Darmenova et al., 2005; Antoine and Nobileau, 2006; Pérez et al., 2006a).

OMAERO is the standard product of the OMI sensor on board of Aura satellite, based on the multi-wavelength UVVIS aerosol algorithm (Levelt, 2002; Torres et al., 2007) in order to calculate AOD. The Aura platform circulates in a sun-synchronous polar orbit with a local afternoon equator crossing time at 13:45 local time, providing global coverage in one day. In this study, we use the daily level-3 AOD product at $500 \mathrm{~nm}$ at $1^{\circ} \times 1^{\circ}$ resolution. The data has to be treated with particular caution due to its weak sensitivity to boundary layer aerosol owing to high desert surface reflectivity (Martin, 2008; Badarinath et al., 2010), or cloud contamination (Hsu et al., 1999). OMI also tends to indicate heavy biomass burning in the Sahel (Basart et al., 2009; Cavalieri et al., 2010) and it may overestimate the winter AOD relative to MISR and MODIS (Ahn et al., 2008; Zhao et al., 2010).

The MODIS instruments onboard the Terra and Aqua platforms have been used extensively for global mapping of AOD. It measures backscattered solar radiation at seven wavelength bands dedicated to aerosol retrieval. MODIS AODs are most reliable over the ocean being moderately biased over arid regions (Kinne et al., 2003; Remer et al., 2005; Levy et al., 2007; Drury et al., 2008). Here we use the MODIS Deep Blue (MODIS DB) product which is based on an algorithm that uses multiple radiances (blue channels), including the $412 \mathrm{~nm}$ channel derived from the MODIS instrument onboard of the Aqua satellite (Hsu et al., 2004). just as with Aura, it provides near-global daily information of optical depth at $550 \mathrm{~nm}$ wavelength at about $10 \mathrm{~km}$ resolution daily at local noon, allowing for the direct characterization of the origin of individual aerosol sources even over highly reflective sources such as deserts. Here, we use the MODIS Terra and DB level-3 AOD products at $550 \mathrm{~nm}$ and $1^{\circ} \times 1^{\circ}$ resolution.

\subsection{Ground based measurement data}

For a quantitative validation, the model-derived AOD is additionally compared with data from seven AERONET stations. This network of sky calibrated CIMEL Sun photometers measures the direct solar radiance at eight wavelengths and sky radiance at four of these wavelengths on a daily base (Holben et al., 1998). Thereby, measurements are taken every $15 \mathrm{~min}$. It provides AOD at 440 or $500 \mathrm{~nm}$ and Ångström exponent (440-870 nm) (Dubovik and King, 2000; Dubovik et al., 2002b). For this study, level 2.0 data are used exclusively, being quality-assured and cloud-screened. Note that during the data processing from level 1.0 to 2.0, optically thick dust clouds may occasionally disappear. Note also that background aerosol might influence the retrieved values as the Sun photometer measurements represent AODs of the total aerosol column (Heinold et al., 2009). The stations used in this study are shown in Fig. 1 (yellow dots) with their location specified in Table 1. The AERONET data are supplemented by AOD measurements taken during SAMUM-1 at Zagora ground station by means of Sun photometers/sky radiometers (Hoyningen-Huene et al., 2009).

Another important source of observational data is EARLINET, providing systematic lidar observations of vertical 

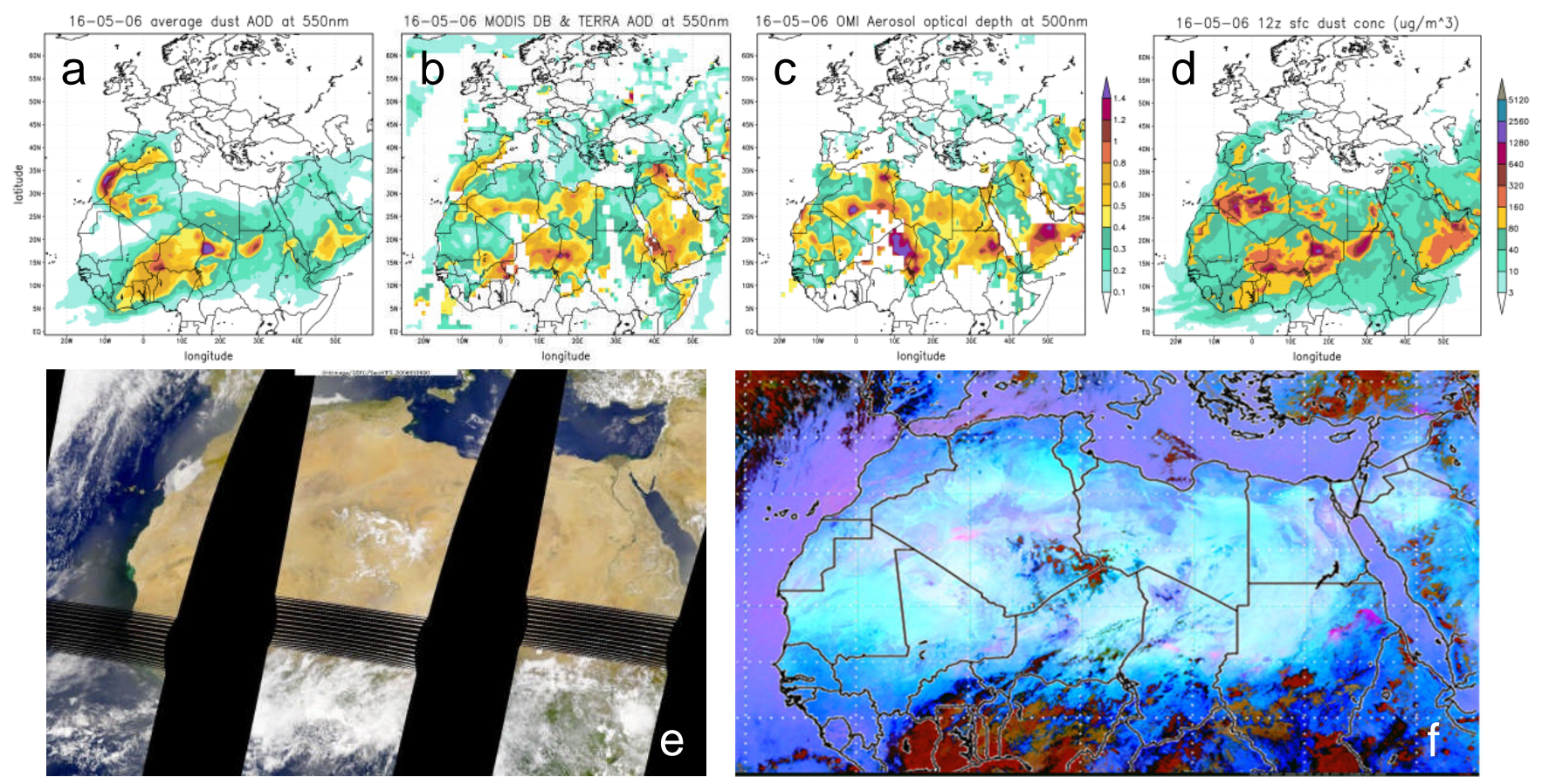

Fig. 2. Four hour average AOD from NMMB/BSC-Dust (a), MODIS Deep Blue and Terra (b), OMI AOD (c), model derived surface dust concentration at 12:00 UTC (d), the SeaWiFS VIS image at 12:00 UTC (e), and the MSG dust image at 12:00 UTC (f) on 16 May 2006 are displayed for the North African domain.

aerosol profiles over Europe on a coherent network basis. Currently, 26 stations across Europe are deployed using elastic backscatter and Raman lidar systems to measure the vertical profiles of the aerosol backscatter and extinction coefficients at various wavelengths between 351 and $1064 \mathrm{~nm}$ (Bösenberg et al., 2003). The EARLINET Raman lidar systems were quality assured performing direct intercomparisons (Matthias et al., 2004; Böckmann et al., 2004). The derived data are finally stored in a central database after cloud screening. Three stations in Southern Europe are chosen for comparison during the SAMUM-1 period as specified in Fig. 1 (green dots) and Table 1.

\section{Results and discussion}

\subsection{SAMUM-1}

\subsubsection{Spatial dust distribution}

We focus on the period 16-21 May 2006. The meteorological situation including the observed spatio-temporal evolution of the dust plume over Northern Africa and Europe is examined in Knippertz et al. (2009). Figures 2 to 7 display the maps of model results and satellite products for this period. For each day, we show a four hour model average AOD which coincides with the passage of the satellite over the region, i.e. between 11:00 and 15:00 UTC, the modeled surface dust concentration at 12:00 UTC, a combined map of MODIS DB (over arid and semi-arid areas) and Terra AOD (over ocean and land), the OMI AOD, the modeled $10 \mathrm{~m}$ wind speed, and the SeaWiFS and MSG RGB image at 12:00 UTC.

Satellite images outline the dust source activation in central Algeria and a pronounced dust plume over Mali, Niger and Chad on 16 May (see Fig. 2b, c, e, f). The dust was advected from Algeria in an easterly direction towards the Moroccan coast and further driven anticyclonically along the coastline towards the Iberian Peninsula. The model is generally consistent with MODIS DB over main activation spots, although these are not always precisely located (Fig. 2a, d). The model reproduces the dust in the Bodélé Depression (Chad), at the border between Niger and Burkina Faso, mostly over central Algeria, off the Moroccan coast and over southern Saudi Arabia, in good agreement with MODIS DB, SeaWiFS VIS and MSG. Over Niger, western Mali and Mauritania, OMI AOD estimates are considerably higher than those from the model and the MODIS DB product, likely due to a mixture with biomass burning aerosols in OMI. Similar mismatch is found over eastern Algeria.

While the model misses out the dust over the northern part of Libya, the AOD over northwestern Sudan is overestimated. The MSG RGB image confirms the active sources over central Algeria and Chad, but indicates - consistent with OMI - dust activation over eastern Sudan which is missed by the model. It is induced by convective activity over southeast 

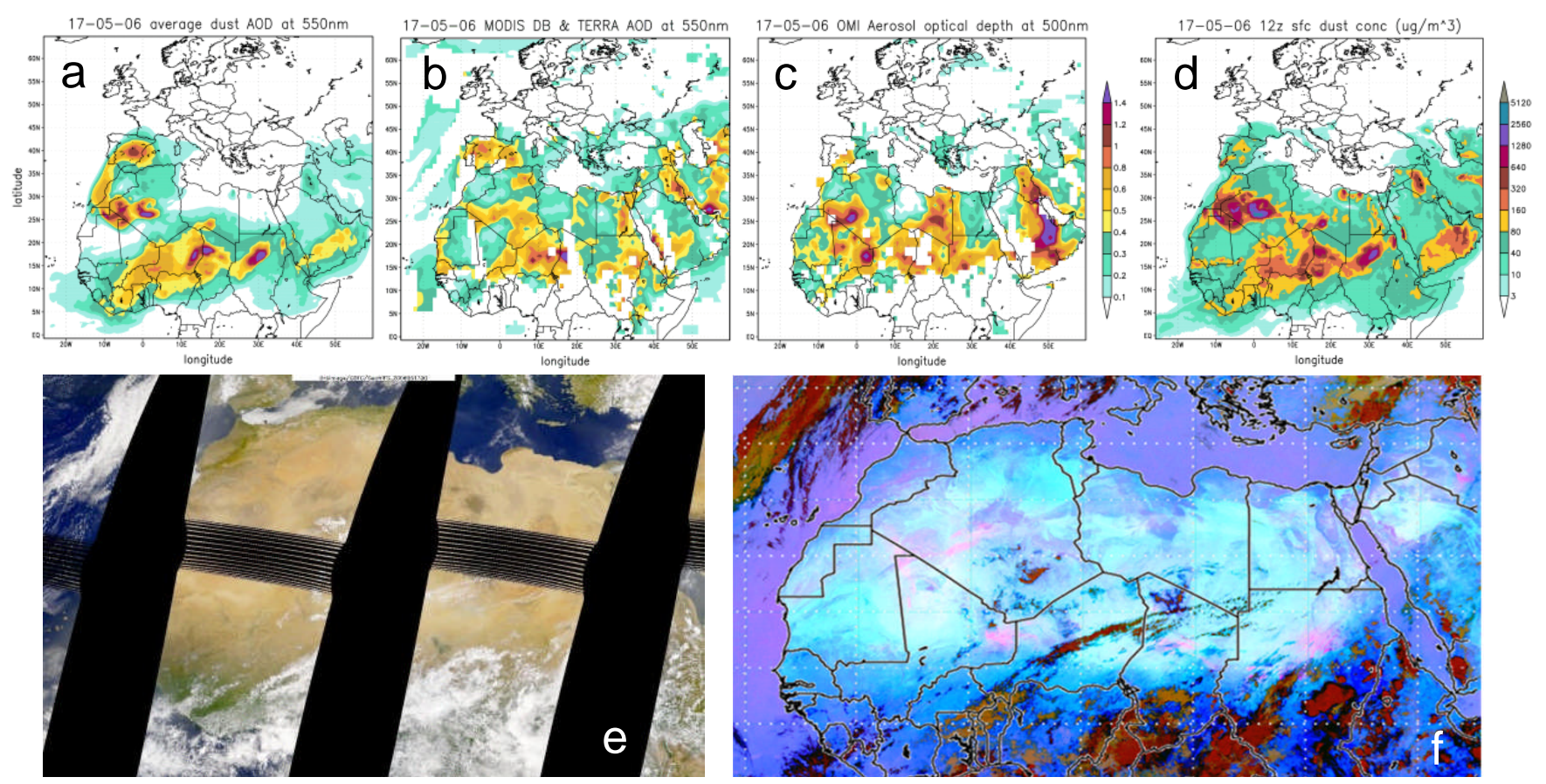

Fig. 3. The same as in Fig. 2, but for 17 May 2006.
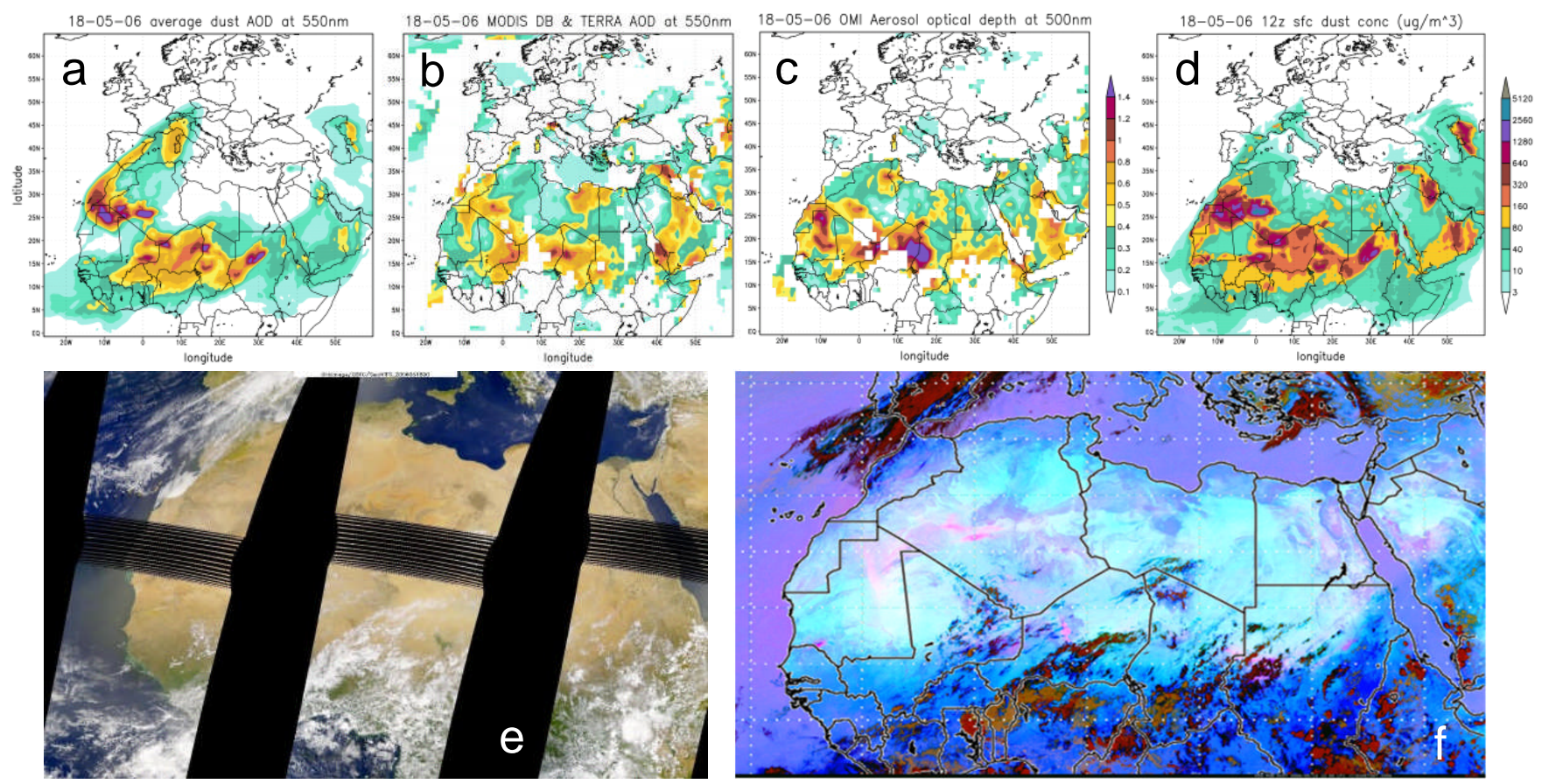

Fig. 4. The same as in Fig. 2, but for 18 May 2006.

Sudan in the morning hours of that day which the model fails to resolve at $0.25^{\circ} \times 0.25^{\circ}$ resolution. SeaWiFS and MSG RGB indicate low dust concentrations off the coast of Western Sahara and Mauritania which is not present in the model. It is attributable to previously emitted dust which was ad- vected at higher altitudes in the wake of the approaching front and was hence partly outside the model domain.

On 17 May (see Fig. 3a-f), the dust advected along the Moroccan coast led to extensive dust loading over the central and eastern Iberian Peninsula. The modeled AOD 

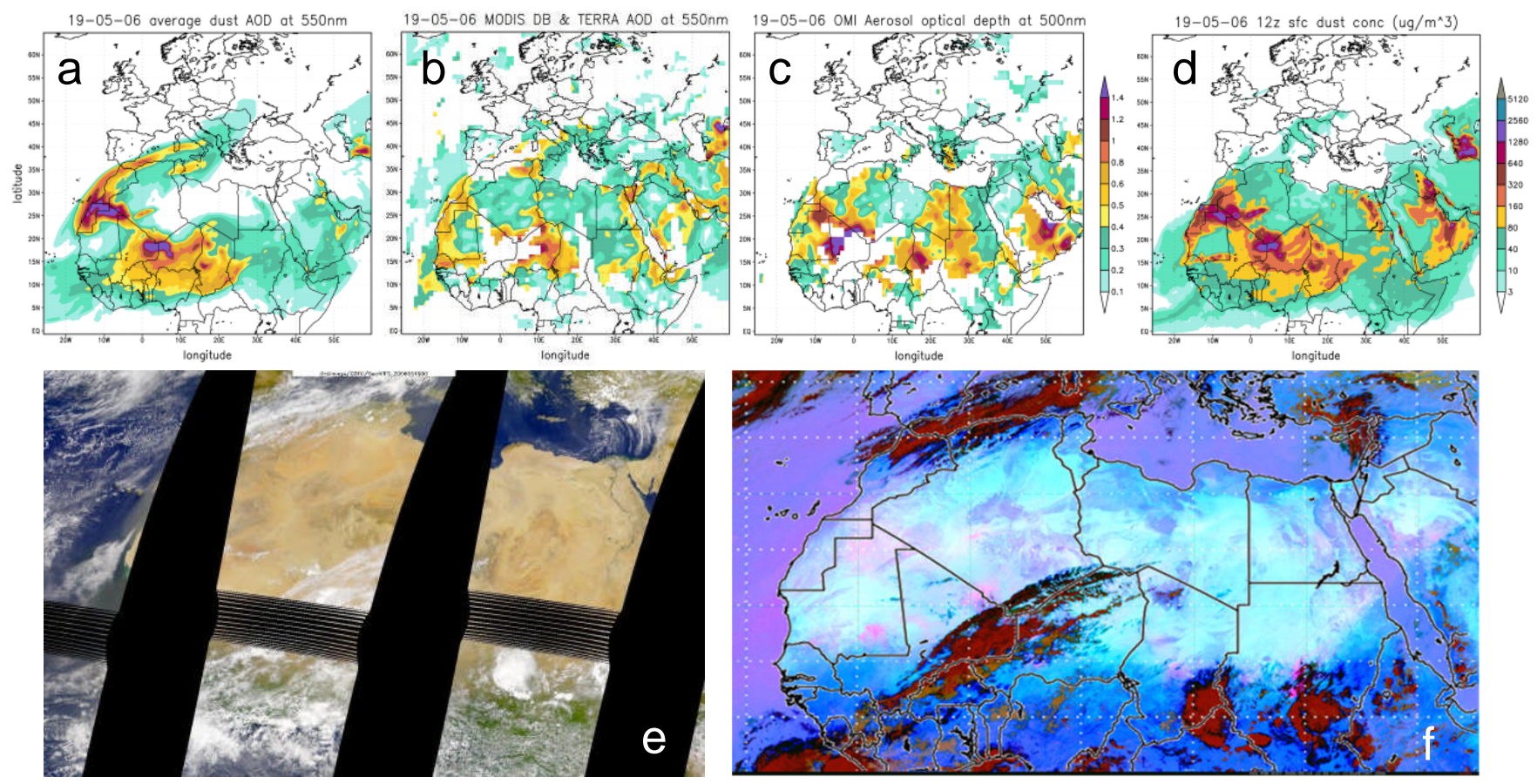

Fig. 5. The same as in Fig. 2, but for 19 May 2006.
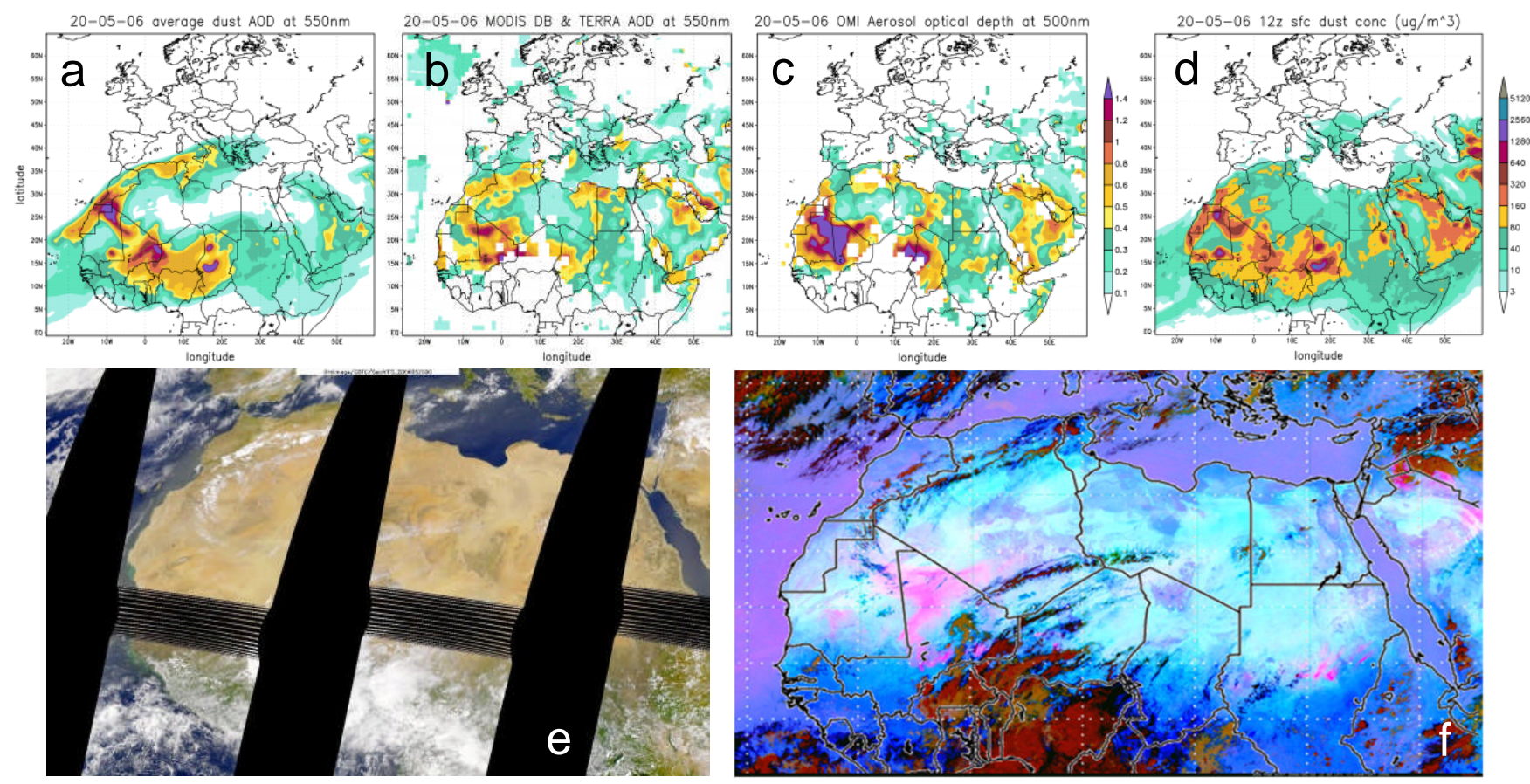

Fig. 6. The same as in Fig. 2, but for 20 May 2006.

corresponds well with MODIS DB and Terra. To the south of the Iberian Peninsula, the model matches also the SeaWiFS image east of its overflight gap. Dust source activation in Chad (Bodélé) is placed correctly in the model compared with MODIS DB. The model also simulates the dust emission from northern Sudan as visible in the MSG image. The model AOD over eastern Libya is underestimated compared to OMI, which itself overestimates when compared with MODIS DB with weak correspondence in the MSG image. Better agreement between OMI and MSG is found 

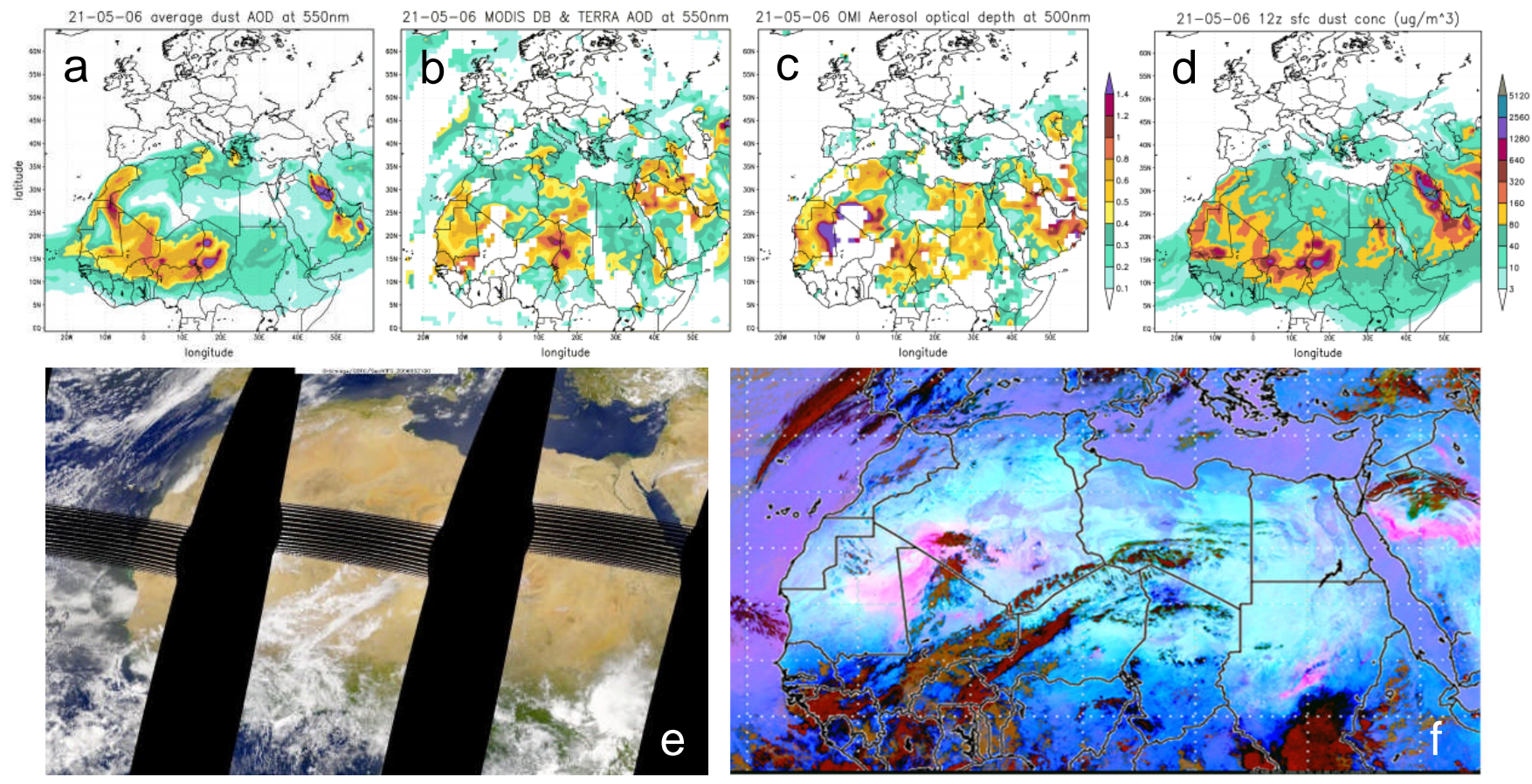

Fig. 7. The same as in Fig. 2, but for 21 May 2006.

in eastern Mali, where only minor dust source activation is simulated. No clear conclusion can be drawn over the Arabian Peninsula, given the rather strong disagreement between MODIS DB and OMI AOD.

On 18 May (see Fig. 4a-f) the model shows a dust plume stretching over the western Mediterranean Sea and northern Italy, as weakly indicated by MODIS Terra and OMI. Dust production in Mali, Niger, Chad and Sudan is placed correctly in the model. Again, the moderate AOD over northern Libya in the retrievals is not captured by the model. Poor agreement is found between OMI and MODIS DB AOD in Mauritania, where the MSG RGB retrieval suggests moderate dust occurrence in the north (weak presence in MODIS DB only), including a stretch of heavy dust in south-central Algeria. The latter is adumbrated in the model, MODIS DB and OMI. However, AOD over central Mauritania is clearly underestimated in the model. In turn, OMI potentially overestimates the AOD compared to MODIS DB, especially in the Niger/Chad border region including the Bodélé Depression.

The dust event over southern Europe covers the Mediterranean Sea including large portions of Italy and the Balkan Peninsula on 19 May (see Fig. 5a-f). The simulated dust pattern is consistent with MODIS DB, Terra and SeaWiFS VIS product (over Sicily). It is partly obscured from clouds in the MSG dust image, although identifiable along the Moroccan coast. MSG also shows dust source activation in the north and south of Mauritania, as well as in southern Algeria, confirming the modeled surface dust concentration to a large extent. As already seen on previous days, the model shows that significant amounts of dust were liberated at the northern tip of Mauritania, corresponding fairly well with OMI AOD but not with MODIS DB.

In the late afternoon hours on 19 May, an interesting synoptic evolution was observed with deep moist convection developing over north-eastern Mali. In the night of 19 to 20 May the induced precipitation due to convection and the associated evaporational cooling caused the formation of a large haboob, whose leading edge quickly spread north and westwards (Knippertz et al., 2009). OMI AOD and MSG RGB show dust mobilization mainly occurring over Mali, resulting in an large dust plume over northern Mali, the southern tip of Algeria, eastern Mauritania and western Chad at noon on 20 May (see Fig. 6a-f). The model is not able to capture the intensity of the event due to an inaccurate representation of the moist convection as discussed in previous modeling studies (Haustein et al., 2009; Heinold et al., 2009) and as evident in the simulated $10 \mathrm{~m}$ wind speed which is rather smoothly distributed and not exceeding moderate velocities (not shown). Nonetheless, the pattern of the modeled $\mathrm{AOD}$ at least resembles the shape of dust plume in the DB retrieval. Over the Bodélé, the modeled AOD agrees well with MODIS DB, while the MSG dust image suggests rather low AOD values.

Finally, the model, SeaWiFS and OMI consistently show the Mediterranean dust outbreak. Although the model fails to reproduce the intense moist convective event, dust is still liberated intensively at the leading edge of the cold pool outflow 

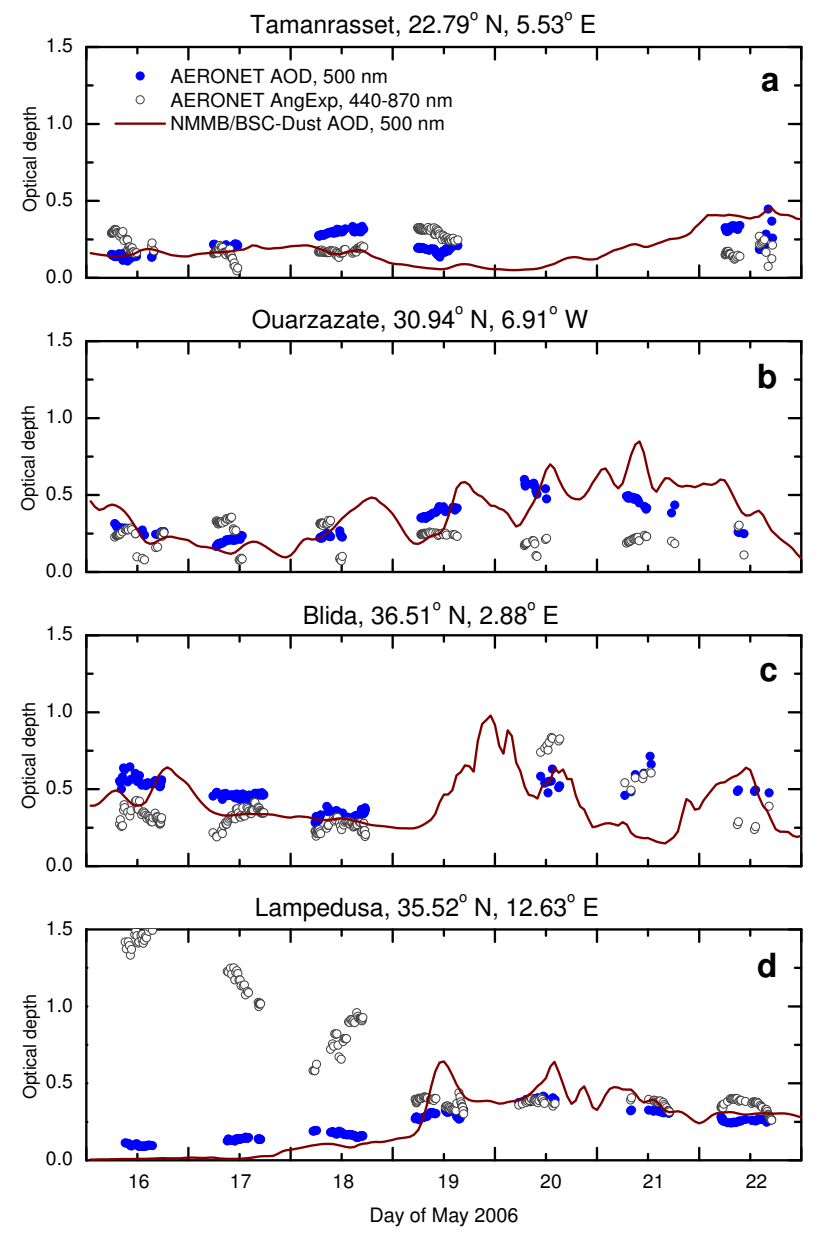

Fig. 8. Model derived AOD (brownish line) versus AERONET AOD (blue dots) and Ångström exponent (black circles) for the period of 16-22 May at Tamanrasset (a), Ouarzazate (b), Blida (c), and Lampedusa (d).

over Mauritania and Mali on 21 May (see Fig. 7a-f). As on 20 May, OMI shows a strong signal in terms of AOD while MODIS DB is considerably less sensitive, indicating that the model reproduces the shape of the dust plume over Mauritania. Moreover, the high AOD values evident in the OMI retrieval are not fully confirmed by the MSG dust image over eastern Mauritania in particular. The model matches also the MODIS DB AOD over the Bodélé with slight overestimation to its south.

\subsubsection{Aerosol optical depth}

In Figs. 8 and 9 we show the comparison of AOD between eight stations (seven AERONET stations including the additional Sun photometer measurements taken during the SAMUM-1 campaign at Zagora) and NMMB/BSC-Dust for the period 16-22 May 2006.
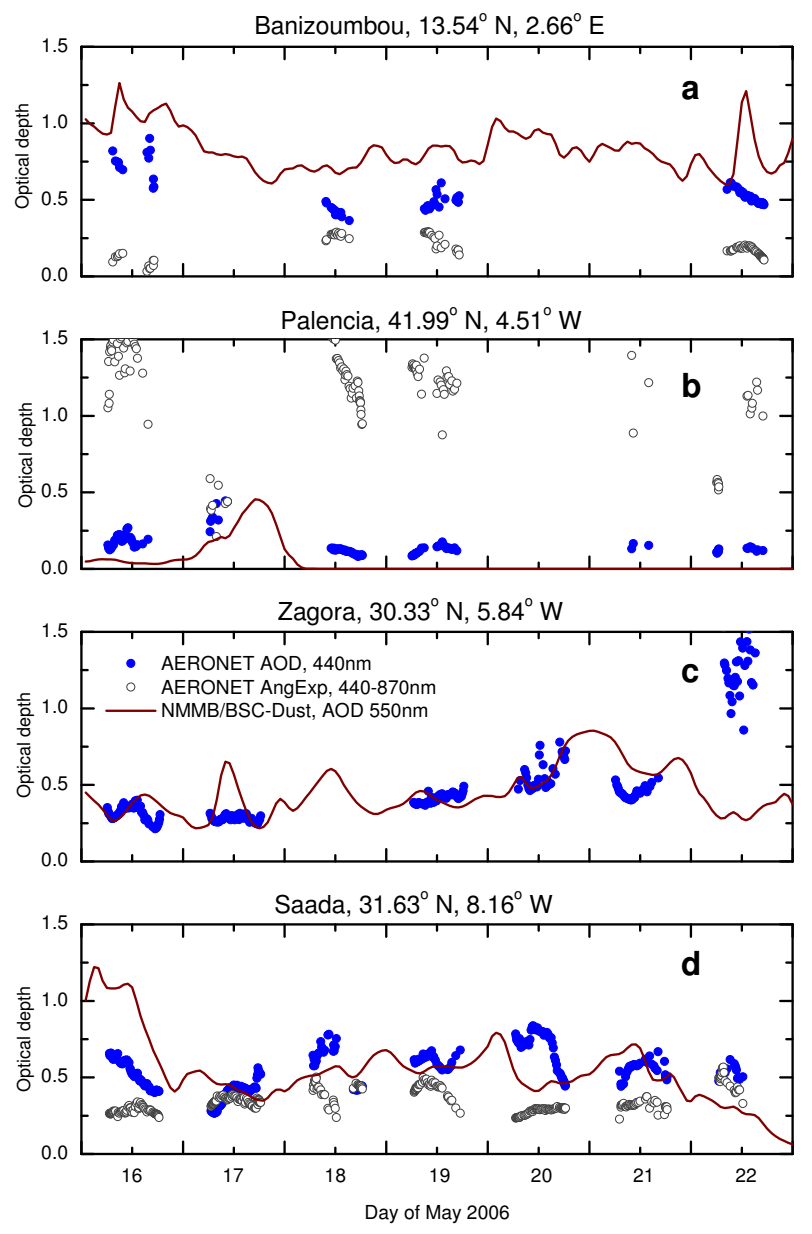

Fig. 9. The same as in Fig. 8, but at Banizoumbou (a), Palencia (b), Zagora (c), and Saada (d).

Ångström exponent values $>0.6$ indicate significant influence of fine-mode anthropogenic aerosols while values $<0.6$ are typical for coarse-mode dust aerosols (Dubovik et al., 2002a; Basart et al., 2009). For example, in Lampedusa anthropogenic aerosol was dominant on 16-18 May, while a dust event beginning on 19 May was observed and successfully simulated in the model. It also reproduces the dust AOD close to dust sources (Tamanrasset) and away from sources (Lampedusa and Palencia). Only on 16 May at Saada the model overestimates the AOD. In general there is a satisfactory agreement at Ouarzazate, Zagora and Saada stations between model and observations. Notice also, that the model simulates a weak diurnal dust cycle at Ouarzazate and Zagora. The impact of the large haboob on 20 May is not observed in the in-situ measurements due to their location. In Banizoumbou, the model overestimates the AOD, which remains rather constant at values between 0.7 and 0.8 during the period due to a (potentially overestimated) persistent dust transport by trade winds from Saharan sources. 


\subsubsection{Vertical dust distribution}

Data from BERTHA and HSRL lidar taken during the field campaign are complemented by EARLINET data. The location of the stations is given in Fig. 1 and Table 1. Figures 10 and 11 show measured (blue) and model-derived (brown) vertical profiles of the extinction coefficient in chronological order. Also the modeled dust load is provided. The altitude is relative to sea level and the model profiles over Ouarzazate are truncated at $1.7 \mathrm{~km}$ height due to model topography. The relative uncertainties provided for the HSRL lidar extinction coefficient are 8-22\% and those for the BERTHA lidar, estimated from the backscatter coefficients, are 10-20\% (Tesche et al., 2009).

As discussed in Knippertz et al. (2009), an upper-level ridge present over northwestern Africa transported dust from eastern and central Algeria along the Moroccan coast towards the Iberian Pensinsula and from there further across southern Europe to Greece where the dust plume arrived on 20 May. While high dust load is observed continuously over Ouarzazate, Saada and Zagora (see Figs. 8 and 9), it is present over Palencia on 17 May and arrives at Lampedusa on 19 May. Backward trajectories calculated on 19 May for the four Italian EARLINET stations (not shown) confirm the anticyclonic track from western Algeria across the Iberian Peninsula (Müller et al., 2009). The dust was then prevailing over Italy and Greece. Backward trajectories calculated on 21 May for Athens and Thessaloniki show a path similar to those arriving at the Spanish and Italian stations, but the corresponding airmass is delayed by about 2 or 4 days depending on the station (Müller et al., 2009).

At noon on 17 May (Fig. 10a), BERTHA indicates a well mixed planetary boundary layer (PBL) over Ouarzazate, between the surface and $5 \mathrm{~km}$, which is consistent with the vertical humidity profile taken at 10:35 UTC as shown in Fig. 12a. While both lidar and radiosonde profiles consistently show the mixing height (MH) to be at $\sim 4.6 \mathrm{~km}$, it is underestimated by the model whose simulated PBL does not show any tendency to grow before late afternoon. At lower levels between 2 and $3 \mathrm{~km}$, the model overestimates the dust extinction by almost a factor of 2 . Since a layered structure of the PBL was repeatedly observed during the field campaign, the small secondary peak at $4.5 \mathrm{~km}$ height could well be an indication of a residual layer from the previous day. The layering is generated when the previous day mixed layer becomes decoupled from the surface due to nocturnal cooling and remains as residual layer until eroded by the formation of the new mixed layer (Heinold et al., 2009; Knippertz et al., 2009).

The next day at 11:00 UTC (Fig. 10b), the model exhibits a layer between 4 and $5 \mathrm{~km}$ height not visible in the lidar profile and overestimates the extinction at lower levels. The vertical profile over Naples at 19:00 UTC (Fig. 10c) is qualitatively captured by the model, however slightly overestimated above $3 \mathrm{~km}$ and mixed too high up to mid-tropospheric levels. The latter cannot be explained by strong vertical motion due to high lapse rates, since no distinct deep convection takes place in the model on that particular day. The vertical profile over Ouarzazate at 21:00 UTC (Fig. 10d) shows that the model captures the height of the dust layer, but it overestimates the BERTHA extinction coefficient by more than a factor of 2, reaching values as high as $140 \mathrm{Mm}^{-1}$.

On 19 May at 11:00 UTC (Fig. 10e), again the model underestimates the $\mathrm{MH}$ and overestimates the low level extinction due to weak vertical mixing. The model profile three hours later at 14:00 UTC (orange dashed line) agrees better with the observations with the MH being placed between 4 and $5 \mathrm{~km}$ height. As on 18 May, the modeled dust and the humidity profiles (Figs. 10e and 12c) are very similar. Note also that Fig. 12 includes complementary wind profiles (radiosonde and model) over Ouarzazate which show model overestimation close to the ground but good overall agreement at higher levels, where the wind field is not influenced by orography.

As shown for Naples on 18 May, dust is transported towards Greece and the eastern Mediterranean mainly between 3-7 km altitude. The eastern edge of the dust plume reaches Thessaloniki on 20 May, as illustrated by the modeled extinction profile (Fig. 11a) with a maximum at $3 \mathrm{~km}$ height. Terra AOD confirms the arrival of the dust plume. However the lidar observation shows a lesser vertical extension and a lower maximum plume height. Note that higher low level extinction coefficients in the lidar profiles (first $2 \mathrm{~km}$ above ground) over Athens and Thessaloniki (particularly obvious in Fig. 11d) are due to anthropogenic aerosols.

On 21 May at 14:00 UTC, the model strongly overestimates the dust plume in Athens (Fig. 11b). Satellite observations indicate that the dust plume had moved further south. The orange dashed line depicts the modeled vertical dust distribution at 18:00 UTC which better matches the lidar profile. Hence the spatial mismatch between model and observation can also interpreted as a temporal mismatch of a few hours. At 19:00 UTC the same day (Fig. 11c) the model captures the observed vertical distribution while the dust slowly moved south. The remaining dust can be seen over Athens at 11:00 UTC on 22 May (Fig. 11d) with a peak altitude between 2 and $3 \mathrm{~km}$ which is captured by the model. At lower levels the lidar signal is strongly affected by anthropogenic aerosols.

Beginning on 20 May over Morocco, a second dust event, induced by low pressure over Tunisia, Algeria and Libya and accompanied by strong southwesterly mid-level winds over the Iberian Peninsula and the western Mediterranean, advected a plume over the Mediterranean Sea, Corsica and Sicily towards Italy, where it arrived in the late hours of 22 May. Over Naples (Fig. 11e), the model overestimates the dust at $\sim 3 \mathrm{~km}$ height. The respective dust extinction cross-section (not shown) revealed that the upwind-induced vertical transport of the dust layer across the Apennines was accelerated in the model, which led to the advection of an 


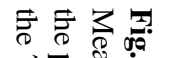

ठ융.

ఫृ

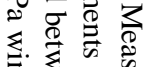

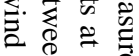

울

言

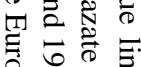

उ융

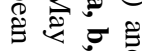

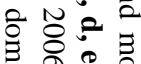

$z=0$

के

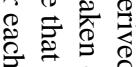

륭

क.

ㄴ. 훙

要 的

递总

구ㅇㅝㅛ

気 吕

的. 蛋

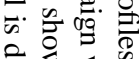

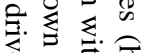

@

․․

㐘寻

กิ๊

車递

乙웡

○芯导

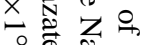

)

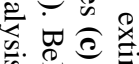

8 远

車 $\overrightarrow{0}$

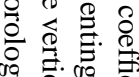

19. त्र. तa

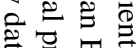

总兽常

후웡

客. 嵒

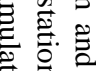

范

空宫题

\& 8

要

空

递

谷萬
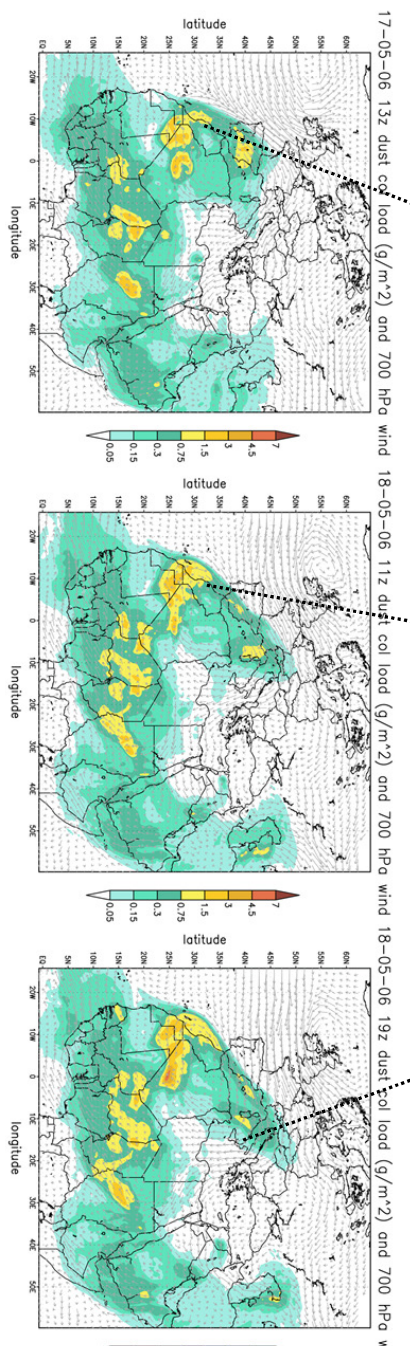

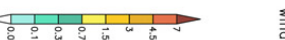

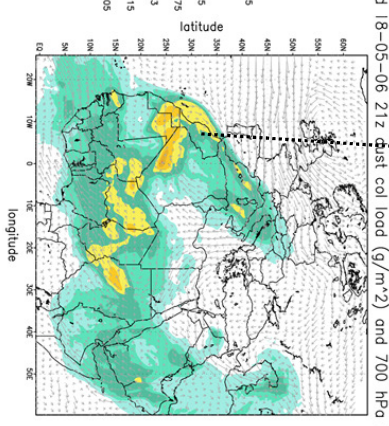

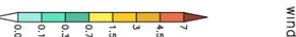

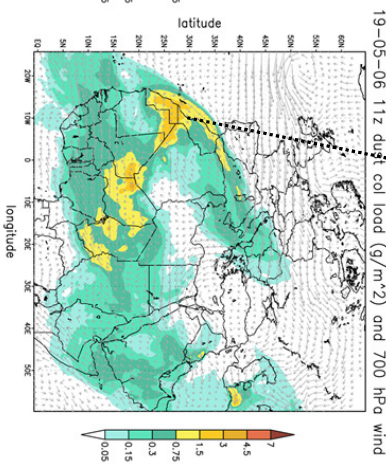

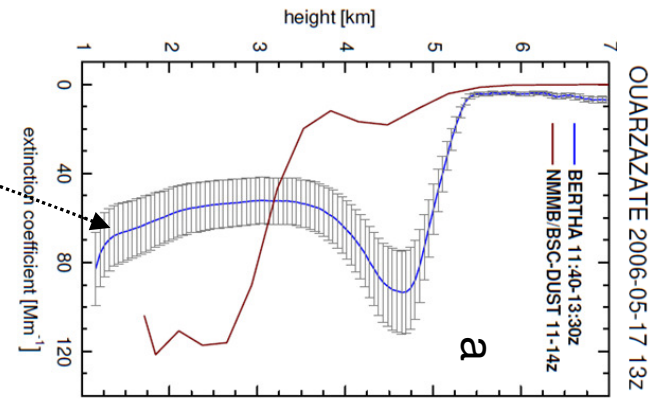
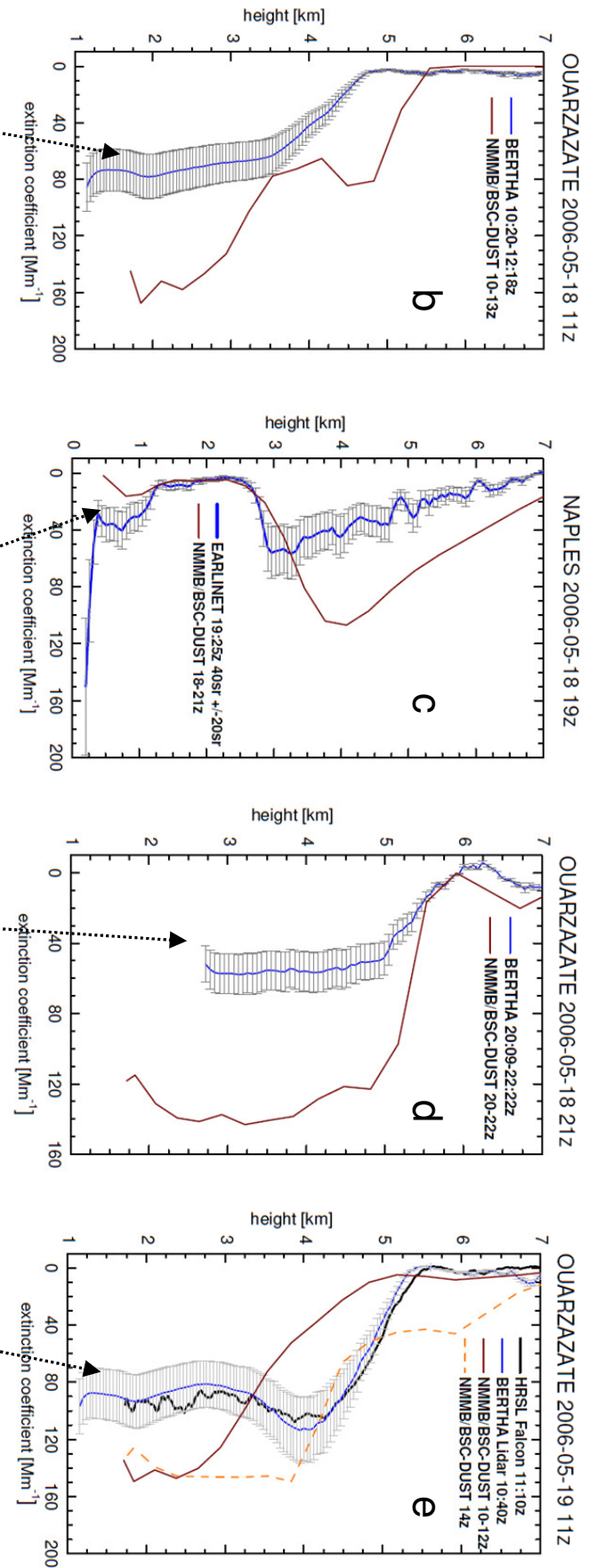

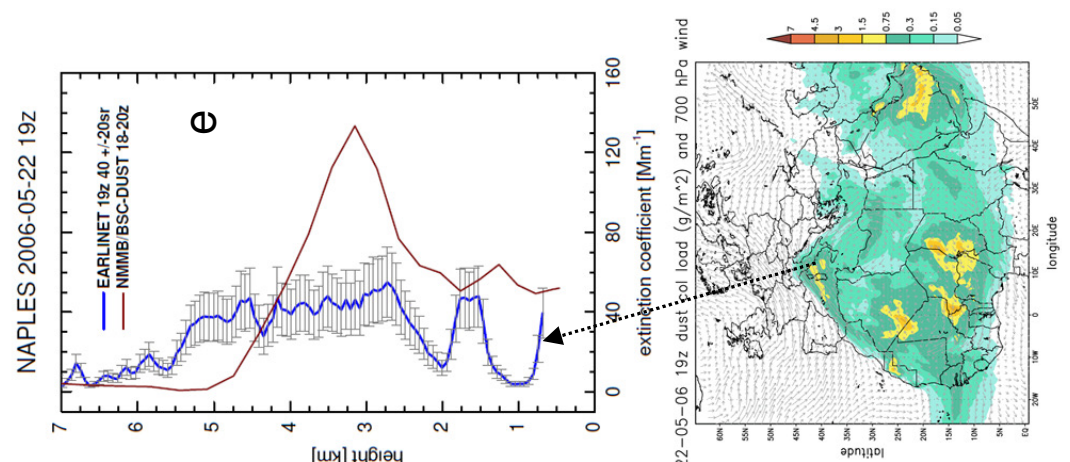

0
0
0
0
0
0
0
0
0
0
0
0
0
0
0
0
0
0
0
0
0
0
0
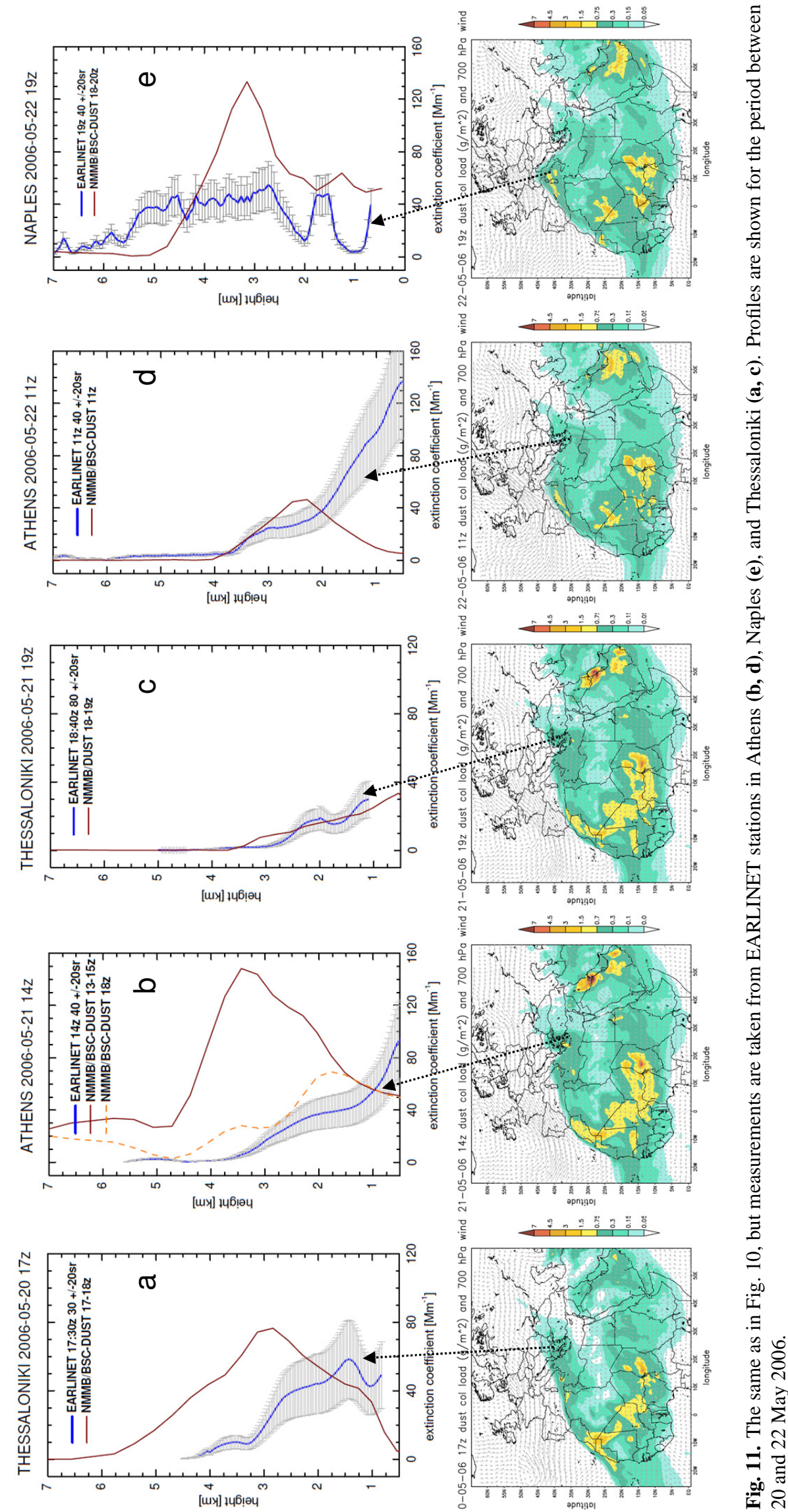

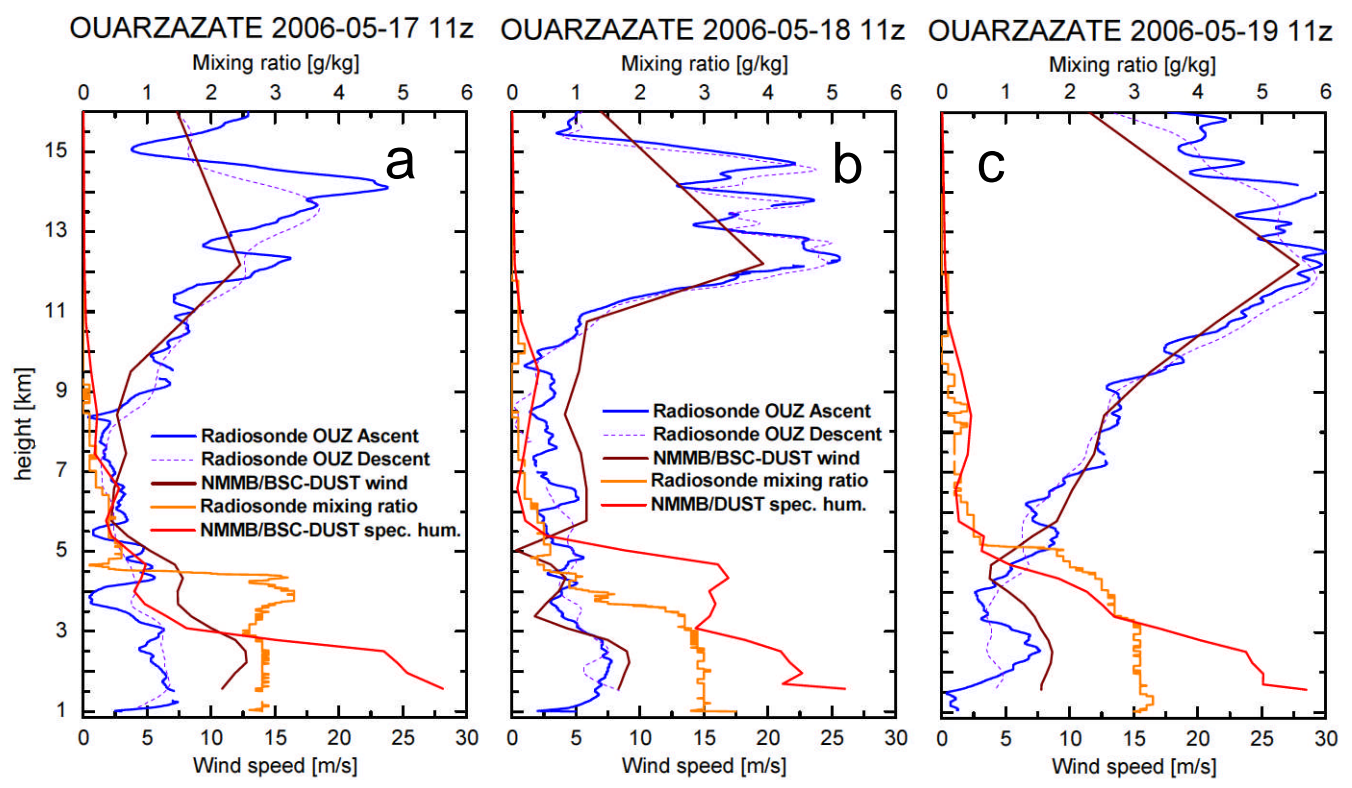

Fig. 12. Vertical profile of wind speed (blue, brown), specific humidity (red), and mixing ratio (orange) over Ouarzazate between 17-19 May 2006 is shown $(\mathbf{a}-\mathbf{c})$. Comparison of simulated winds versus that derived from morning radiosonde launch.
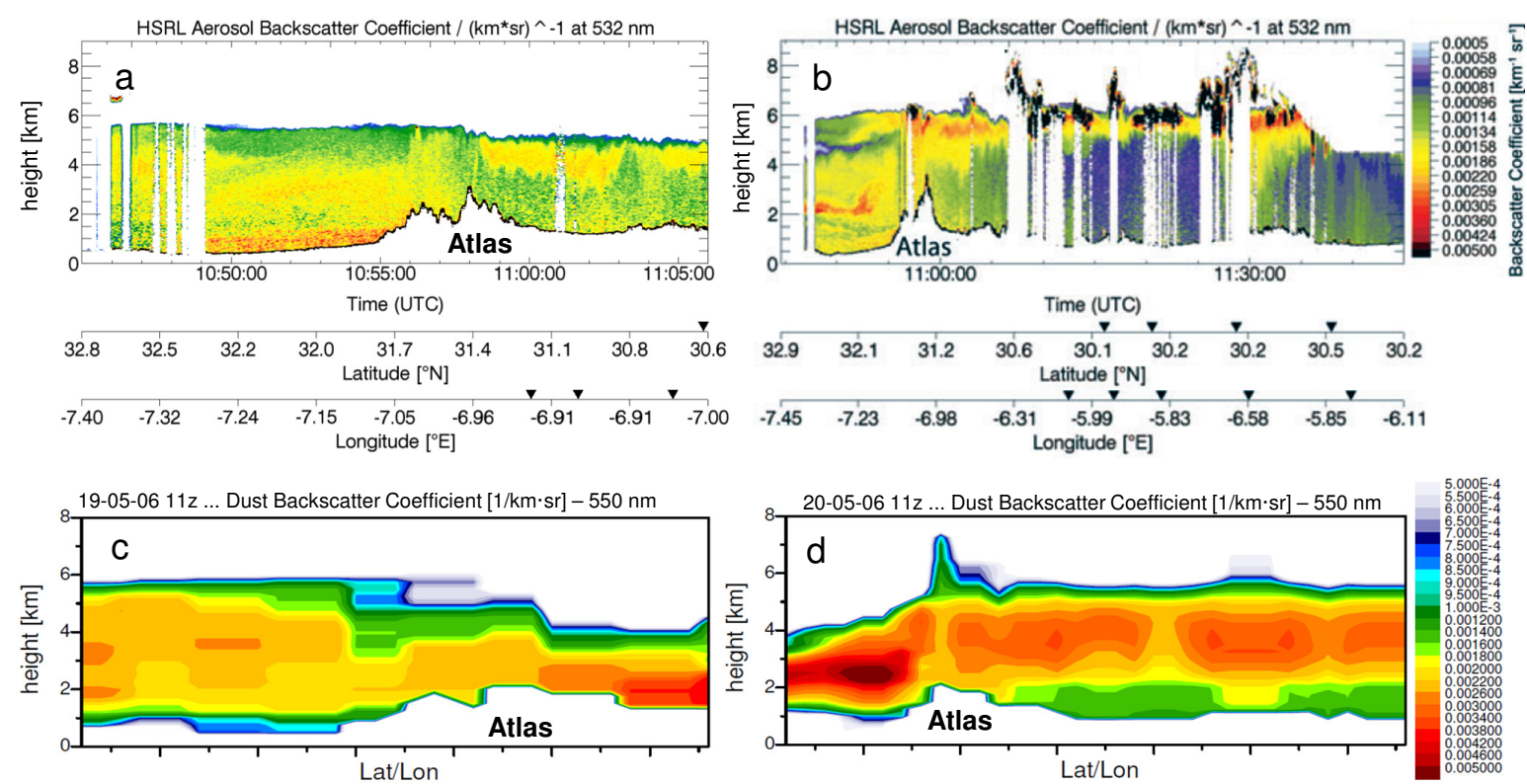

Fig. 13. Vertical cross-section of dust backscatter coefficient during the Falcon overflight from Casablanca to Ouarzazate on 19 and 20 May 2006. Lidar data from Falcon flight measurements (a, b) versus model-derived backscatter coefficient at $550 \mathrm{~nm}$ (c, d) are shown. Arrows on the longitude/latitude axis indicate changes in the flight direction of the aircraft. The model coordinates (c, d) correspond with those from the overflight.

optically thin dust plume towards the south, affecting Naples such that the simulated model result does not match the observed lidar profile. It is thus a local mesoscale phenomenon of short duration, highly influenced by the model topography.

Figure 13 shows two backscatter lidar profiles acquired during two Falcon overflights in the morning hours of 19 and
20 May (see red line over the Ouarzazate and Zagora area in Fig. 1). Both profiles are characterized by a well mixed structure of the dust layer (Weinzierl et al., 2009). For the evaluation of the backscatter coefficient, we assume a vertically constant LR of $50 \mathrm{sr}$ although it can vary with time and height considerably (Esselborn et al., 2008; Tesche et al., 
2009). The HSRL cross-section illustrates a homogeneous dust layer on 19 May, with a rather constant backscatter coefficient from the surface up to $5 \mathrm{~km}$ height, attributable to a well mixed turbulent PBL topped by a strong inversion. The corresponding vertical profile is shown in Fig. 10e, revealing that the model slightly underestimates the height of the PBL. The same pattern is found in the model cross-section, which appears more heterogeneous with higher dust concentration in the lowermost layers. Fairly good agreement can be seen further north over the Atlas Mountains, both regarding $\mathrm{MH}$ and stratification.

No clouds disturb the measurements on 19 May. In contrast, some cirrus cloud at $6 \mathrm{~km}$ height obscured the underlying aerosol layer on 20 May. On 20 May, the HSRL crosssection illustrates an elevated dust layer, centered at 5-6 km height to the southeast of the Atlas Mountains. Knippertz et al. (2009) suggest differential advection during the night and subsequent mixing as a possible mechanism to explain this distribution. The pronounced dust layer to the northwest of the Atlas Mountains at $\sim 2 \mathrm{~km}$ height is reproduced by the model, although overestimated. Over the mountain range, the dust is transported vertically due to mountain waves in the model. The dust layer is thicker and appears at a lower altitude than in the observations that were made to the southeast of the Atlas Mountains. The top height of the mixed PBL at $5.5 \mathrm{~km}$ is well captured by the model, but the rather stratified well mixed dust layer does not match the observation. Given the moderate overestimation over the Mauritania/Morocco border region in terms of AOD in the model, too much dust is persistently transported to the southwest of the Atlas Mountains compared to the satellite imagery (see Fig. 6a-c).

\subsubsection{Particle number size distribution}

The surface size distribution at Tinfou (from a combined DMPS and APS measurement) and the particle size distribution over Ouarzazate on 19 (11:00 UTC) and 20 May 2006 (13:00 UTC) at $3.2 \mathrm{~km}$ and at $\sim 5 \mathrm{~km}$ height are shown in Fig. 14a-f. On both occasions, the heights correspond with the 520 and $670 \mathrm{hPa}$ level in Fig. 14g-k, which shows the modeled longitudinal and latitudinal dust extinction crosssections at the time of the Falcon overflights. It illustrates the influence of the orography upon the modeled spatial dust distribution.

Apart from very large particles, the dust size spectra near the surface are well captured. This is also true for the results we obtain in the free troposphere, except at $4.8 \mathrm{~km}$ height on 19 May, when the model underpredicts the number concentration due to a low dust MH (see Fig. 10e). The MH is higher in the small band of high extinction coefficients visible at $6^{\circ}$ E between $550-600 \mathrm{hPa}$ in Fig. 14j, which is placed just east of the overflight track in the model. Nonetheless, the simulated size spectrum agrees with the observations on 19 and 20 May, demonstrating that the model is able to repro- duce the dust particle size distribution. Very large particles $(>10 \mu \mathrm{m})$ at the surface are underestimated from the model since their limited atmospheric residence time prevents them from being further uplifted due to gravitational settling. This feature cannot be fully resolved by the model given its vertical resolution with the first layer being representative for the lowermost $80 \mathrm{~m}$ in our case. Hence, the average dust particle size does not entirely reflect the measured surface size distribution as discussed in Haustein et al. (2009). Moreover, highly variable surface wind speeds may have affected the measurements implying uncertainties as discussed in Schladitz et al. (2009) and Kandler et al. (2009). Particles $<0.2 \mu \mathrm{m}$ in diameter are most likely not related to dust, rather than to other aerosol species (Schütz et al., 1981), thus being not considered in the model. Also, particles $>20 \mu \mathrm{m}$ in diameter are not taken into account as they are contributing to long-range transport only to a minor degree (Middleton et al., 2001).

\subsection{BoDEx}

In this section, we analyze the period 1-11 March 2005 over the Bodélé. The dust annual cycle in this region follows a semi-annual pattern with peaks in the boreal spring and fall (Washington et al., 2006a,b). The considered early spring case is characterized by days with and without dust source activation, but with generally lower emission rates than in late spring. Days 10 and 11 of March 2005 were substantial dust emission days with strongly restricted surface visibility over the measurement site in Chicha, accompanied by other moderate events on 3-7 and 9 March. The synoptic pattern during this episode was mainly characterized by a negative March North Atlantic Oscillation (NAO) index, favoring a weak Azores anticyclone, which in turn featured a precession of low-pressure systems from southwest to northeast across the Mediterranean and a blocking anticyclone west of the British Isles as observed at the beginning of the month. Between 9-12 March, the blocking anticyclone over the northeastern Atlantic suddenly migrated eastward, extending a very strong ridge of high pressure across Northern Africa in the form of a redeveloped Libyan high (Washington et al., 2006a).

Several dust modeling studies have been conducted using the BoDEx dataset (e.g. Tegen et al., 2006; Bouet et al., 2007; Todd et al., 2008a). Tegen et al. (2006) tested several input parameters in their emission scheme with a box model, and compared dust emissions calculated with the observed wind speeds to those calculated with wind speeds from their regional model. Todd et al. (2008b) compared five regional dust atmospheric models including BSC-DREAM8b, in terms of meteorology, dust emission and transport. Among other results, Todd et al. (2008b) reported strong near-surface wind speed underestimations, an unresolved out-of-phase relationship of the diurnal cycles of the LLJ and the surface 

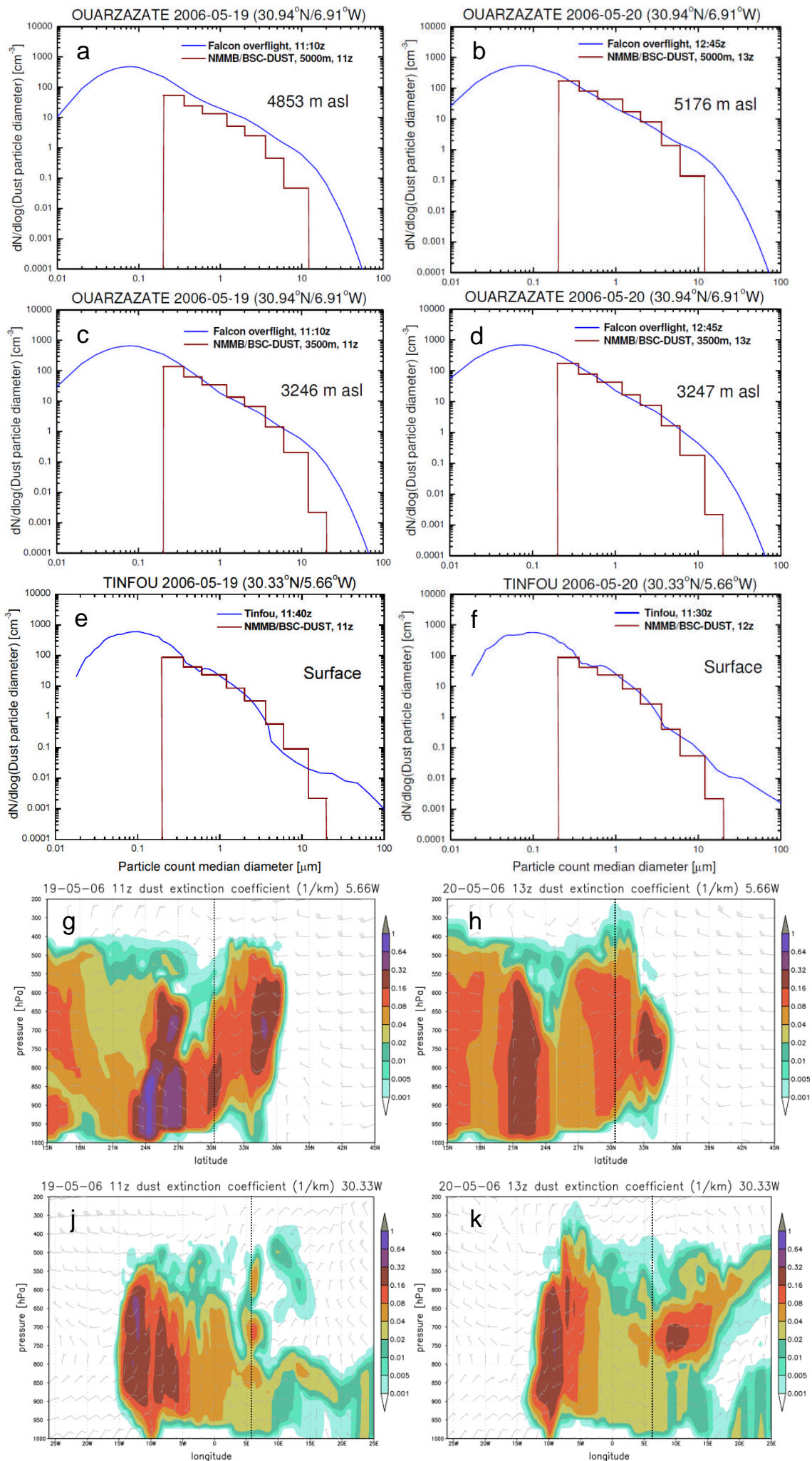

Fig. 14. Measured (blue line) and model derived particle size distribution (brownish line) at 19 and 20 May 2006 over Ouarzazate at $5 \mathrm{~km}$ (a, b) and $3 \mathrm{~km}(\mathbf{c}, \mathbf{d})$ altitude, and at the surface in Tinfou $(\mathbf{e}, \mathbf{f})$. Notice the truncated ordinate, causing the largest model size class to be out of range $(\mathbf{a}, \mathbf{b})$. Complementary, the latitudinal $(\mathbf{g}, \mathbf{h})$ and the longitudinal $(\mathbf{j}, \mathbf{k})$ model extinction cross-section and wind bars are shown. The location of the Tinfou/Ouarzazate region is marked with the dotted line. 

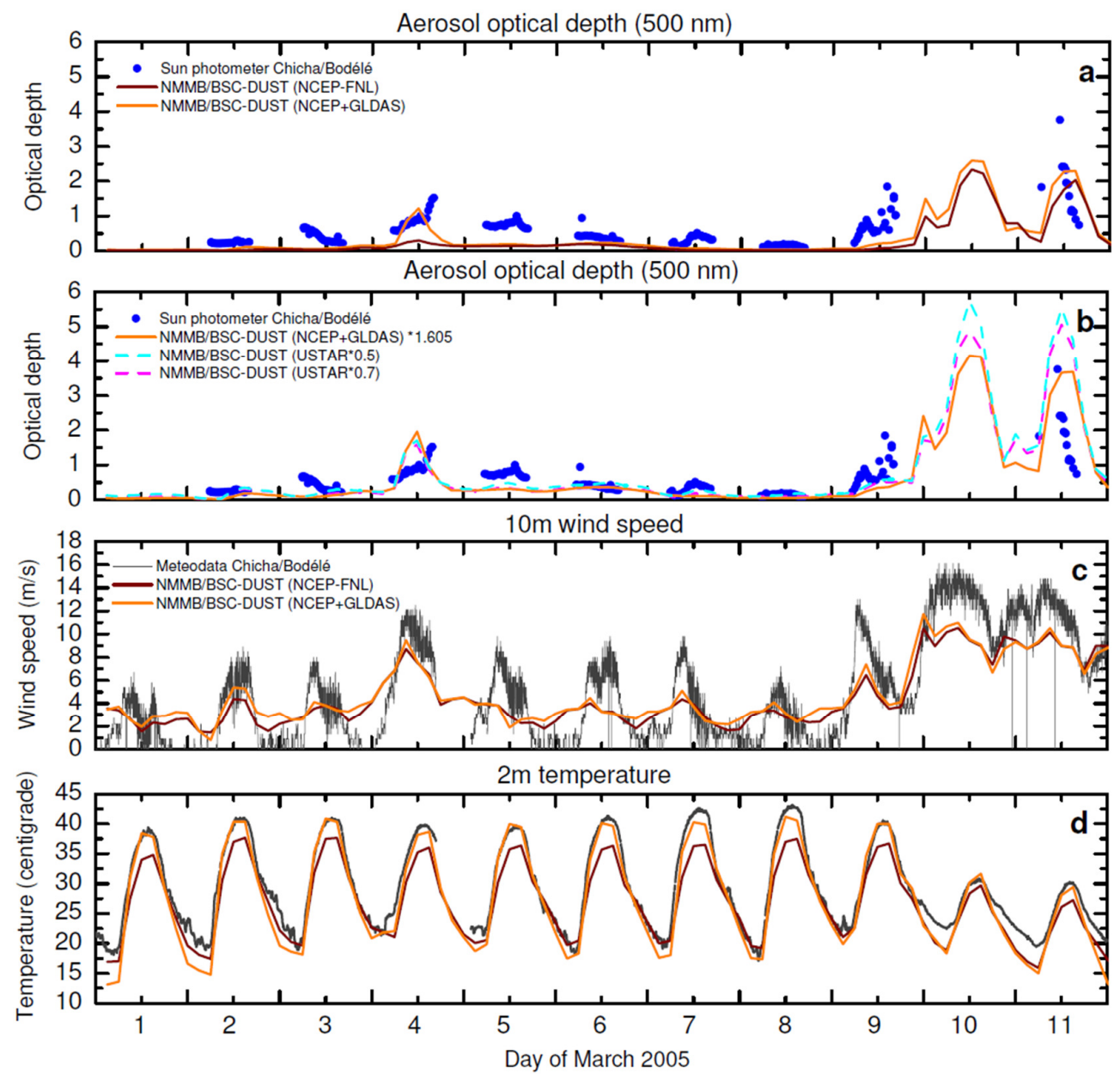

Fig. 15. Model derived AOD (a, b), $10 \mathrm{~m}$ wind speed (c) and $2 \mathrm{~m}$ temperature (d) (brown and orange solid lines) over the Bodélé versus AOD from Sun photometer (a, b) (blue dots) and wind speed (c) and temperature at the surface (d) from meteorological observations (grey solid line) at Chicha for the period 1-11 March 2005. The dashed cyan and pink lines refer to the alternative model setup as indicated in the legend (b).

winds in most models and an order of magnitude difference in the AOD among models.

Below we evaluate and analyze the skills of the $\mathrm{NMMB} / \mathrm{BSC}$-Dust to reproduce the meteorology and the dust patterns in this prominent dust source. We also detail the performed model experiments, which were all initialized using $1^{\circ} \times 1^{\circ} \mathrm{NCEP}$ FNL analysis atmospheric data.

\subsubsection{Surface meteorology and dust emission}

Time series of modeled and observed dust AOD, $10 \mathrm{~m}$ wind speed and $2 \mathrm{~m}$ temperature for the period 1-11 March at Chicha are displayed in Fig. 15. For reference, Chicha is located in western Chad south of the Tibesti Mountains (blue dot in Fig. 1).

The first model experiment (NCEP-FNL) was initialized with NCEP FNL analysis soil moisture and soil temperature fields. In this case, the comparison with observations reveals a strong AOD underestimation over the entire period, particularly on days 4,9 , and 11 (Fig. 15a). AOD measurements are not available on 10 March due to the reduced visibility associated with the heavy dust storm (Washington et al., 2006a; Todd et al., 2007). On 11 March, the model underestimates the AOD peak and shows a temporal delay with respect to the observed AOD in the afternoon. As shown in Fig. 15c the model underestimates the daily maximum surface wind up to $50 \%$ while it usually overestimates the nighttime winds. We also found a systematic cool temperature bias during the day as strong as $10 \mathrm{~K}$ (Fig. 15d), which suggests a poor soil moisture initialization. We tested the latter hypothesis in a second experiment (NCEP-GLDAS) by running the model using soil initial conditions from the Global Land Data Assimilation System (GLDAS) calculated with the Noah Land Surface Model (Ek et al., 2003).

In general, NCEP-GLDAS captures the amplitude of the $2 \mathrm{~m}$ temperature due to a more realistic (drier) soil moisture 
respresentation over the region for this case. Zender et al. (2003a) already reported that NCEP soil moisture is usually too high over active dust emission regions all year long, which hampers its use in dust models. NCEP-GLDAS underestimates the minimum temperature on 1, 2, 10 and 11 March and the maximum temperature on 7 and 8 March. Since our simulations do not explicitly account for dust radiative effects, the high dust loading on 10 and 11 March, which should inhibit outgoing LW radiation to reach higher levels, may at least partly explain the observed nocturnal temperature difference. Also the slight overestimation of the maximum temperature on 10 March may be an indicator of the neglected dust SW radiative cooling effect in the simulation. The drier soil moisture in NCEP-GLDAS has consequences over the simulated dust as it reduces the threshold wind friction velocity and as it slightly increases the maximum daily wind speed with respect to NCEP-FNL (Fig. 15c). The latter is due to an increased mixing of momentum down to the ground driven by an enhanced surface sensible heat flux. In comparison to NCEP-FNL, NCEP-GLDAS shows a slightly higher dust AOD on the 9,10 and 11 March and a significantly higher AOD on 4 March, which is closer to observations. However, the AOD underestimation remains very strong over the study period due to the underestimated winds in the model.

Tegen et al. (2006) performed simulations at $7 \mathrm{~km}$ resolution with a regional model. While the use of higher resolution helped developing stronger daily winds compared to our $25 \mathrm{~km}$ resolution simulation, the daily wind peaks remained underestimated and nighttime wind speeds overestimated with respect to observations. In their study, the use of a Weibull probability distribution to account for sub-gridscale variability of surface winds resulted in a better AOD agreement over the 3-7 March period, but also in an unrealistically high AOD (above 100) for the 9-11 period.

Motivated by the shortcoming of the model to reproduce the maximum surface wind speeds at this resolution, observed particularly on 5-7 and 9 March, we conducted three additional experiments. First, we increased the horizontalto-vertical-flux-ratio $(\alpha)$ in the emission scheme by a factor that minimized the AOD model error. In our model we follow an empirical relationship by which the vertical dust flux is proportional to the horizontal sand flux. $\alpha$ is the coefficient of proportionality reflecting the availability of dust in the soil, which is calculated as the sum of $\alpha$ of each soil population class weighed by their mass fraction in the soil (Pérez et al., 2011). $\alpha$ in the model for the Bodélé is estimated to be $3.6 \times 10^{-6} \mathrm{~cm}^{-1}$. In this experiment we multiply $\alpha$ by 1.605 , the factor which gives lowest bias in comparison with Sun photometer AOD. In two other experiments we reduced the threshold friction velocity by 30 and $50 \%$, which is approximately the range of underestimation when we compare the modeled and observed diurnal wind speeds. The results are displayed in Fig. 15b. On 4 March, the three experiments overestimated the AOD in the morning hours. As expected, all three experiments are generally closer to the observations over the rest of the period. In particular, the reduction of the threshold friction velocity by $50 \%$ significantly helps reducing the bias of the model for the period of 5-9 March. Also, the model emits more dust on 10 and 11 March in the three experiments. However, the delay of the model on 11 March hampers any definite conclusion about the modeled intensity for this event.

In Fig. 16 we show model and satellite dust distributions centered over the Bodélé for 4, 10 and 11 March. As expected, MODIS DB (Fig. 16d) places the highest AOD over the Bodélé and features significant dust activity in surrounding regions. The model captures qualitatively many of the dust patterns observed from the satellite observations (Fig. 16a). The differences among the model experiments are mainly quantitative and there are no remarkable differences in the qualitative patterns (Fig. 16a-c). The improvements achieved by increasing the value of the horizontal-tovertical-flux-ratio or reducing the threshold friction velocity are also confirmed by comparison with satellite data.

The model clearly captures the shape and extent of the main dust plume emitted from the Bodélé. On 4 March the model reproduces the dust activity in southern Libya, northern Chad and Nigeria visible in the satellite maps. The model does not show much of the freshly emitted dust over central Sudan - due to a southward progressing front or density current - as clearly visible in the MSG RGB product (Fig. 16e). The significant dust load in Niger highlighted in MODIS DB is not represented in the model. This roughly coincides with the presence of clouds in the MSG RGB product, which suggests cloud contamination in the MODIS DB AOD retrieval. On 10 and 11 March very high AOD values are present over the Bodélé. On 10 March the model captures the extent of the Bodélé dust plume and reproduces the dust activity in northern Niger close to the border with Chad and Libya and at the Niger-Algeria-Mali border crossing. On 11 March, MODIS DB and MSG RGB indicate that the dust plume extends further south as far as Cameroon and Nigeria. The model agrees well on both days, only significantly underpredicting the AOD over southwestern Niger on 11 March.

\subsubsection{Bodélé Low Level Jet}

The Bodélé Depression is dominated by the northeasterly Harmattan winds of Northern Africa in all months except July and August, when the intertropical convergence zone moves sufficiently far north to bring light and variable winds over the Bodélé (Washington et al., 2006a). These northeasterly winds are likely to be accelerated between the Tibesti and Ennedi Massifs (Koren and Kaufman, 2004), supporting a pronounced easterly LLJ, evident also in the wind data from NCEP reanalysis with maximum wind speeds at $925 \mathrm{hPa}$ overlying the Bodélé area (Washington and Todd, 2005; Todd et al., 2008b) (not shown). Usually, this LLJ feature is clearly present until May, when it is partly superimposed and 

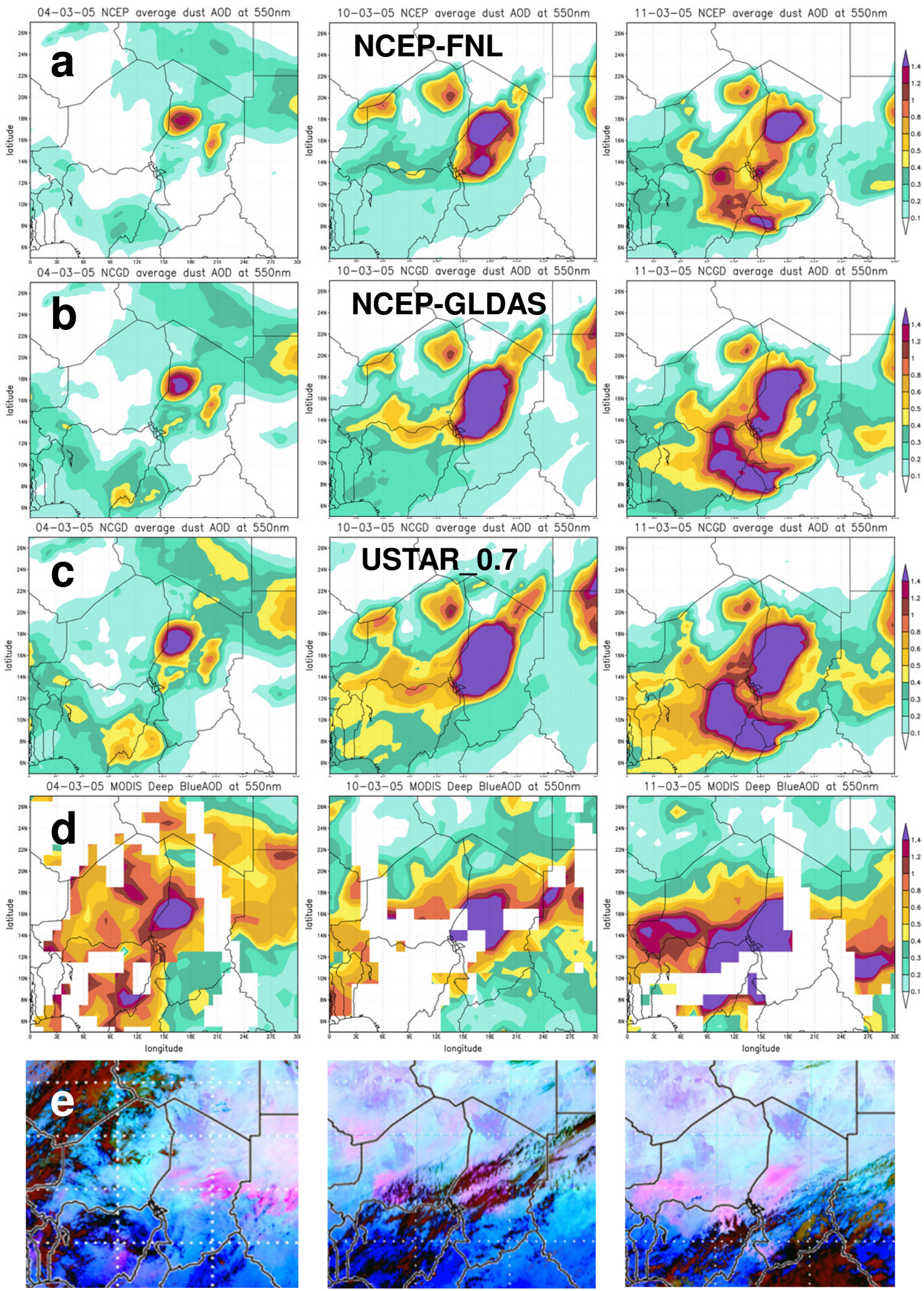

Fig. 16. Four hour average of model AOD for the 3 experiments: NCEP-FNL (a), NCEP-GLDAS (b), NCEP-GLDAS with reduced threshold friction velocity (c). MODIS DB AOD (d) and MSG dust image at 12:00 UTC (e) on 4, 10, 11 March 2005 are displayed for the limited regional domain $\left(5^{\circ} \mathrm{N}\right.$ to $27^{\circ} \mathrm{N}$ and $0^{\circ} \mathrm{W}$ to $\left.30^{\circ} \mathrm{E}\right)$. 
PIBAL sonde observed wind speed

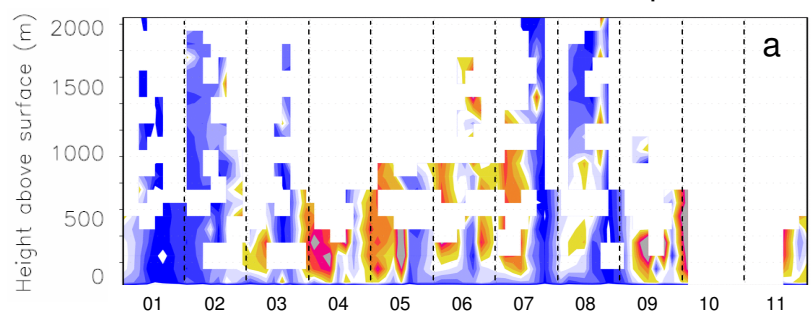

NCEP (FNL) 1 x 1 degree analysis

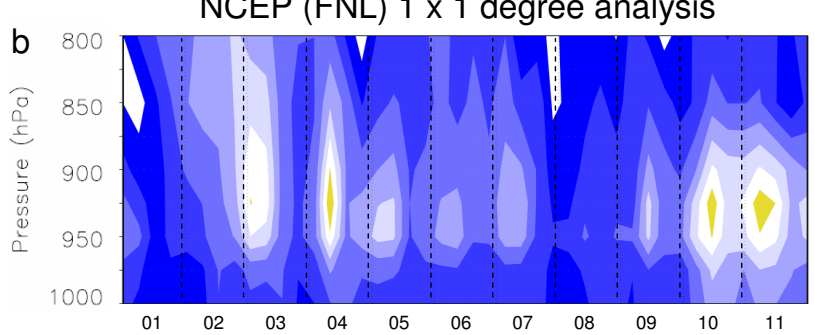

NMMB (NCEP $1 \times 1$ degree analysis)

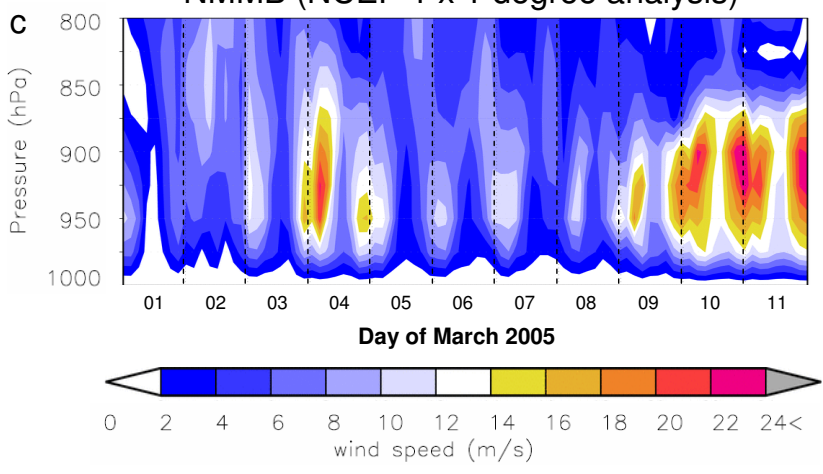

Fig. 17. Time-height profile of wind speed $\left(\mathrm{m} \mathrm{s}^{-1}\right)$ at Chicha as derived from PIBAL balloon data (a), NCEP analysis $1^{\circ} \times 1^{\circ}$ data (b) and NMMB/BSC-Dust initialized with NCEP analysis and GLDAS soil conditions (c) for the period from 1-11 March 2005. Note that height units are either given in $m$ or hPa.

weakened by the African Easterly Jet over the Sahel. It is absent to the west and weakens to the south. It disappears south of $10^{\circ} \mathrm{N}$ and north of $22^{\circ} \mathrm{N}$ as described by Washington and Todd (2005). During the BoDEx campaign, the Bodélé LLJ with its pronounced diurnal cycle was evident under dusty as well as dust-free conditions (Washington et al., 2006a). Wind speeds are at maximum in the midmorning hours with calm conditions at night when the vertical turbulent flux is at minimum due to absent surface heating. Although wind was peaking at $10 \mathrm{~m} \mathrm{~s}^{-1}$ at dust-free days, it was not high enough to cause dust deflation. At dusty days, the amplitude of the diurnal cycle was similar to dust-free days but with winds speeds peaking well above $14 \mathrm{~m} \mathrm{~s}^{-1}$. According to Washington et al. (2006a), the corresponding wind speed threshold coinciding with deflation, suspension and saltation of dust is $12 \mathrm{~m} \mathrm{~s}^{-1}$. Winds in excess of $12 \mathrm{~m} \mathrm{~s}^{-1}$ were observed during the Bodélé dust outbreak between 9-12 March.
In Figure 17, the temporal evolution of the vertical wind profile over Chicha is shown as measured from PIBAL (a), derived from NCEP FNL analysis (b) and simulated from the model with NCEP FNL atmospheric analysis and GLDAS soil conditions (c). While NCEP reanalysis data intrinsically underestimates the surface wind during daytime hours by more than $60 \%$ on occasion (Koren and Kaufman, 2004; Todd et al., 2008b), the NCEP analysis underestimation of the low level wind is still more than $50 \%$ (see Fig. 17b). The poor resolution of the diurnal wind cycle is probably due to difficulties of the NCEP model to resolve smaller boundary layer features at the given vertical and spatial resolution. Taking into account the clear underestimation of the vertical NCEP wind field, the model reproduces the observed wind speeds surprisingly well. Although lower, the model peak winds of approximately $20 \mathrm{~m} \mathrm{~s}^{-1}$ are much closer to the observed wind maxima which reach wind speeds in excess of $24 \mathrm{~m} \mathrm{~s}^{-1}$ at night. The general pattern - with highest wind speeds observed on 4 March and during the Bodélé dust outbreak - is well reproduced with some underestimation on 6 and 7 March. The midmorning Bodélé LLJ is captured not only in its vertical extension but also regarding the diurnal temporal evolution. However, as shown at the surface, the model misses the peak wind speeds mostly on 5-7 and 9 March. Apart from the weaker LLJ at those days, the PIBAL data also suggest that the potential momentum provided by the LLJ was not transported down to the surface. However, it is effectively mixed down by turbulence especially on 4, 10 and 11 March, consistent with modeled surface wind speeds (compare Fig. 16). At $25 \mathrm{~km}$ resolution, the model reproduces the typical LLJ over the Bodélé and satisfactorily simulates the diurnal wind cycle at the surface, although it underestimates the peak wind velocities at days with moderate average wind speeds.

\section{Conclusions}

In the companion paper (Pérez et al., 2011), we described the new NMMB/BSC-Dust model and we presented a general evaluation of the model at global and regional scales for years 2000 and 2006, respectively. In this paper we have evaluated and analyzed in detail the behavior of the model making use of the data provided by two of the most important and recent dust experimental campaigns in Northern Africa. All the simulations presented in this contribution were run at $25 \mathrm{~km}$ resolution, which is expected to be the standard model resolution for dust forecasting at BSC.

For the SAMUM-1 campaign investigated in this study, we examined the model's capability to reproduce the dust spatial and vertical distribution, and the dust size spectra at different height levels. For the second campaign investigated in this study, BoDEx, we focused on the model behavior to represent the meteorology and the dust patterns in the Bodélé 
Depression, which is probably the most prolific dust source on Earth.

During the SAMUM-1 period (16-21 May 2006), the model describes fairly well the general dust patterns in Northern Africa. On 19 May, the strong dust deflation triggered by deep moist convection developed over Mali and Mauritania is, to a large extent, not reproduced by the model. The transport path towards Europe and the Mediterranean is in good qualitative agreement particularly with MODIS DB. In terms of dust deflation, inefficiently active dust sources are identified over eastern Mauritania and portions of central Niger, even though the surface winds seem to be higher than the threshold friction velocity required for the initiation of the dust emission process in the model. As discussed in Pérez et al. (2011), the topographic preferential source map used in the model does not reflect the Mali/Mauritania border source leading to underestimation of the emissions in that region. A more comprehensive analysis regarding the dust sources in the model will be the object of a forthcoming study. Close to the Sahel, disagreement between OMI and MODIS DB AOD hampers the validation of the model. OMI generally tends to provide higher AOD values than MODIS DB.

The AERONET comparison during the SAMUM-1 period reveals that the model reproduces the dust quantitatively well close to the sources. For this period, we found a weak daily cycle close to dust sources (Ouarzazate, Zagora), rather constant values in the Sahel (Banizoumbou) and north of the main sources regions (Tamanrasset), and dust longrange transport to Europe (Palencia) and the Mediterranean (Lampedusa) associated with distinguished dust episodes. The comparison with lidars revealed model deficiencies in the vertical distribution. We found temporal disagreement in two cases, strong overestimation in one case and mismatch regarding the $\mathrm{MH}$ in another four cases, particularly over Ouarzazate on 17 and 18 May. The latter is related with the PBL simulated by the model, which shows equal mismatch when comparing the observed WV mixing ratio profile (radiosonde data) and the modeled profile of the specific humidity. The difficult orographic situation over Ouarzazate and its proximity to downstream sources may introduce considerable modeling errors. In this context we would like to stress that the 3-D atmospheric variables of the model act very sensitively upon changes in the initial meteorology data which hence are an additional source of uncertainty.

The particle number size distribution is well captured by the model, although large particles remain underestimated. Nonetheless, the simulated size spectra agrees well with the observations, at the surface as well as at 3 and $5 \mathrm{~km}$ altitude.

We performed several model experiments for the BoDEx period between 1-11 March 2005. We showed the importance of accurate initial soil moisture conditions in the model to reproduce the amplitude of the $2 \mathrm{~m}$ temperature and to better represent the intensity of the diurnal winds in the model. NCEP FNL analysis underestimates the soil water content which led to a substantial cold bias of up to $10 \mathrm{~K}$. When us- ing GLDAS soil moisture data to initialize the model, the diurnal surface temperature range is consistently reproduced with a positive effect upon dust emission over the Bodélé.

At the working resolution of $25 \mathrm{~km}$, the model underestimates up to $50 \%$ the daily maximum wind speed and thus significantly underestimates the dust emission and AOD. However, the persistent dust source activation period peaking over the Bodélé on 10 and 11 March is simultaneously shown by the model and the satellite retrievals. Additional experiments with an increased horizontal-to-vertical-flux-ratio or a reduction of the threshold friction velocity up to $50 \%$ significantly improved the skills of the model. We restricted the soil moisture analysis to the BoDEx period, since the SAMUM-1 field site in Morocco is not directly located within the main source region which would complicate the attribution of potential changes in the simulated spatio-temporal dust distribution. The applied initial soil data may also be subject to annual changes or updates which hamper their interannual comparability.

The wind speed over the Bodélé was evaluated with specific regard to the typical wind pattern which features a persistent diurnal cycle with peak wind velocity between $0.5 \mathrm{~m}$ and $1 \mathrm{~km}$ above ground in the late morning hours: the Bodélé LLJ which was measured during BoDEx with the PIBAL sonde. NMMB/BSC-Dust succeeds to place the maximum wind field correctly in terms of vertical extension and temporal development. Highest wind speeds measured with the PIBAL sonde on 4 and 9-11 March correspond well with maximum wind speeds simulated by the model, showing that the model reproduces the Bodélé LLJ.

Acknowledgements. The authors would like to thank the AERONET program for establishing and maintaining the used sites. We would like to thank the EARLINET program for providing and analyzing the lidar data. We are grateful to Benoit Laurent and LISA for providing high resolution roughness length data. We would also like to express our thanks to the whole SAMUM-1 and BoDEx team, who provided us with in-situ and surface based data gathered during the field campaign. OMI and MODIS daily data used in this paper were produced with the Giovanni online data system, developed and maintained by the NASA GES DISC. The Earth Institute at Columbia University is acknowledged for support through the Cross-Cutting Initiative project: Atmospheric Aerosol impacts on health in sub-Saharan Africa. Finally, we thank two anonymous reviewers for their valuable and helpful comments. This work was developed under the research projects CGL200611879, CGL2008-02818, CGL2010-19652 and CSD00C-06-08924 of the Spanish Ministry of Science and Technology. Simulations were performed with the Marenostrum Supercomputer at the BSC.

Edited by: P. Jöckel 


\section{References}

Ahn, C., Torres, O., and Bhartia, P. K.: Comparison of Ozone Monitoring Instrument UV Aerosol Products with Aqua/Moderate Resolution Imaging Spectroradiometer and Multiangle Imaging Spectroradiometer observations in 2006, J. Geophys. Res., 113, D16S27, doi:10.1029/2007JD008832, 2008.

Althausen, D., Müller, D., Ansmann, A., Wandinger, U., Hube, H., Clauder, E., and Zörner, S.: Scanning 6-Wavelength 11-Channel Aerosol Lidar, J. Atmos. Ocean. Technol., 17, 1469-1482, 2000.

Antoine, D. and Nobileau, D.: Recent increase of Saharan dust transport over the Mediterranean Sea, as revealed from ocean color satellite (SeaWiFS) observations, J. Geophys. Res., 111, D12214, doi:10.1029/2005JD006795, 2006.

Arakawa, A. and Lamb, V. R.: Computational design of the basic dynamical processes of the UCLA general circulation model, Meth. Comput. Phys., 17, 173-265, 1977.

Badarinath, K., Kharol, S. K., Kaskaoutis, D. G., Sharma, A. R., Ramaswamy, V., and Kambezidis, H. D.: Long-range transport of dust aerosols over the Arabian Sea and Indian region - A case study using satellite data and ground-based measurements, Global Planet. Change, 72, 164-181, 2010.

Bagnold, R. A.: The Physics of Blown Sand and Desert Dunes, Methuen, New York, USA, 265 pp., 1941.

Basart, S., Pérez, C., Cuevas, E., Baldasano, J. M., and Gobbi, G. P.: Aerosol characterization in Northern Africa, Northeastern Atlantic, Mediterranean Basin and Middle East from direct-sun AERONET observations, Atmos. Chem. Phys., 9, 8265-8282, doi:10.5194/acp-9-8265-2009, 2009.

Betts, A. K.: A new convective adjustment scheme. Part 1: Observational and theoretical basis, Q. J. Roy. Meteorol. Soc., 112, 677-691, doi:10.1002/qj.49711247307, 1986.

Betts, A. K. and Miller, M. J.: A new convective adjustment scheme, Part II: Single column tests using GATE wave, BOMEX, ATEX and arctic air-mass data sets, Q. J. Roy. Meteorol. Soc., 112, 693-709, doi:10.1002/qj.49711247308, 1986.

Böckmann, C., Wandinger, U., Ansmann, A., Bösenberg, J., Amiridis, V., Boselli, A., Delaval, A., De Tomasi, F., Frioud, M., Grigorov, I., Hägärd, A., Horvat, M., Iarlori, M., Komguem, L., Kreipl, S., Larchevêque, G., Matthias, V., Papayannis, A., Pappalardo, G., Rocadenbosch, F., Rodrigues, J. A., Schneider, J., Shcherbakov, V., and Wiegner, M.: Aerosol lidar intercomparison in the framework of the EARLINET project. 2. Aerosol backscatter algorithms, Appl. Optics, 43, 977-989, 2004.

Bösenberg, J., Matthias, V., Amodeo, A., Amoiridis, V., Ansmann, A., Baldasano, J. M., Balin, I., Balis, D., Böckmann, C., Boselli, A., Carlsson, G., Chaikovsky, A., Chourdakis, G., Comeron, A., De Tomasi, F., Eixmann, R., Freudenthaler, V., Giehl, H., Grigorov, I., Hagard, A., Iarlori, M., Kirsche, A., Kolarov, G., Kolarev, L., Komguem, G., Kreipl, S., Kumpf, W., Larcheveque, G., Linné, H., Matthey, R., Mattis, I., Mekler, A., Mironova, I., Mitev, V., Mona, L., Müller, D., Music, S., Nickovic, S., Pandolfi, M., Papayannis, A., Pappalardo, G., Pelon, J., Perez, C., Perrone, R. M., Persson, R., Resendes, D. P., Rizi, V., Rocadenbosch, F., Rodrigues, J. A., Sauvage, L., Schneidenbach, L., Schumacher, R., Shcherbakov, V., Simeonov, V., Sobolewski, P., Spinelli, N., Stachlewska, I., Stoyanov, D., Trickl, T., Tsaknakis, G., Vaughan, G., Wandinger, U., Wang, X., Wiegner, M., Zavrtanik, M., and Zerefos, C.: EARLINET: A European Aerosol Research Lidar Network., MPI-Report, Max-Planck-Institut für
Meteorologie, Hamburg, Germany, 348, 1-191, 2003.

Bouet, C., Cautenet, G., Washington, R., Todd, M. C., Laurent, B., Marticorena, B., and Bergametti, G.: Mesoscale modeling of aeolian dust emission during the BoDEx 2005 experiment, Geophys. Res. Lett., 34, L07812, doi:10.1029/2006GL029184, 2007.

Cavalieri, O., Cairo, F., Fierli, F., Di Donfrancesco, G., Snels, M., Viterbini, M., Cardillo, F., Chatenet, B., Formenti, P., Marticorena, B., and Rajot, J. L.: Variability of aerosol vertical distribution in the Sahel, Atmos. Chem. Phys., 10, 12005-12023, doi:10.5194/acp-10-12005-2010, 2010.

Christensen, J. H.: The Danish eulerian hemispheric model - A three-dimensional air pollution model used for the Arctic, Atmos. Environ., 31, 4169-4191, 1997.

D'Almeida, G. A.: On the variability of desert aerosol radiative characteristics, J. Geophys. Res., 92, 3017-3026, 1987.

Darmenova, K., Sokolik, I. N., and Darmenov, A.: Characterization of east Asian dust outbreaks in the spring of 2001 using ground-based and satellite data, J. Geophys. Res., 110, D02204, doi:10.1029/2004JD004842, 2005.

Devara, P. C., Pandithurai, G., Raj, P. E., Maheskumar, R. S., and Dani, K. K.: Atmospheric aerosol-cloud-stability relationship as observed with optical and radio remote sensing techniques, Atmos. Res., 49, 65-76, 1998.

Drury, E. E., Jacob, D. J., Wang, J., Spurr, R. J. D., and Chance, K. V.: Improved algorithm for MODIS satellite retrievals of aerosol optical depths over western North America, J. Geophys. Res., 113, D16204, doi:10.1029/2007JD009573, 2008.

Dubovik, O. and King, M. D.: A flexible inversion algorithm for retrieval of aerosol optical properties from Sun and sky radiance measurements, J. Geophys. Res., 105, 20673-20696, 2000.

Dubovik, O., Holben, B. N., Eck, T. F., Smirnov, A., Kaufman, Y. J., King, M. D., Tanré, D., and Slutsker, I.: Variability of Absorption and Optical Properties of Key Aerosol Types Observed in Worldwide Locations, Atmos. Sci., 59, 590-608, 2002a.

Dubovik, O., Smirnov, A., Holben, B. N., King, M. D., Kaufman, Y. J., Eck, T. F., and Slutsker, I.: Accuracy assessments of aerosol optical properties retrieved from Aerosol Robotic Network (AERONET) Sun and Sky radiance measurements, J. Geophys. Res., 105, 9791-9806, 2002b.

Egger, J., Blacutt, L., Ghezzi, F., Heinrich, R., Kolb, P., Lämmlein, S., Leeb, M., Mayer, S., Palenque, E., Reuder, J., Schäper, W., Schween, J., Torrez, R., and Zaratti, F.: Diurnal circulation of the Bolivian Altiplano - Part I: Observations, Mon. Weather Rev. 133, 911-924, 2005.

Ek, M. B., Mitchell, K. E., Lin, Y., Rogers, E., Grunmann, P., Koren, V., Gayno, G., and Tarpley, J. D.: Implementation of Noah land surface model advances in the National Centers for Environmental Prediction operational mesoscale Eta model, J. Geophys. Res., 108, 8851, doi:10.1029/2002JD003296, 2003.

Esselborn, M., Wirth, M., Fix, A., Tesche, M., and Ehret, G.: Airborne high spectral resolution lidar for measuring aerosol extinction and backscatter coefficients, Appl. Optics, 47, 346-358, 2008.

Esselborn, M., Wirth, M., Fix, A., Weinzierl, B., Rasp, K., Tesche, M., and Petzold, A.: Spatial distribution and optical properties of Saharan dust observed by airborne high spectral resolution lidar during SAMUM 2006, Tellus, 61B, 131-143, 2009.

FAO-UNESCO: Soil Map of the world at 1: 5000000. Volume I, Tech. rep., UNESCO, Paris, France, 1974. 
Fécan, F., Marticorena, B., and Bergametti, G.: Parametrization of the increase of the aeolian erosion threshold wind friction velocity due to soil moisture for arid and semi-arid areas, Ann. Geophys., 17, 149-157, doi:10.1007/s00585-999-0149-7, 1999.

Fels, S. B. and Schwarzkopf, M. D.: The simplified exchange approximation - A new method for radiative transfer calculations, J. Atmos. Sci., 32, 1475-1488, 1975.

Ferrier, B. S., Jin, Y., Lin, Y., Black, T., Rogers, E., and DiMego, G.: Implementation of a new grid-scale cloud and precipitation scheme in the NCEP Eta Model, in: Proceedings of the 15th Conference on Numerical Weather Prediction, 280-283, 2002.

Giles, J.: The dustiest place on Earth., Nature, 434, 816-819, 2005.

Ginoux, P., Chin, M., Tegen, I., Prospero, J. M., Holben, B., Dubovik, O., and Lin, S.-J.: Sources and distribution of dust aerosols simulated with the GOCART model, J. Geophys. Res., 106, 20255-20273, 2001.

Haustein, K., Pérez, C., Baldasano, J. M., Müller, D., Tesche, M., Schladitz, A., Esselborn, M., Weinzierl, B., Kandler, K., and Hoyningen-Huene, W. v.: Regional dust model performance during SAMUM 2006, Geophys. Res. Lett., 36, L03812, doi:10.1029/2008GL036463, 2009.

Heinold, B., Tegen, I., Esselborn, M., Kandler, K., Knippertz, P., Müller, D., Schladitz, A., Tesche, M., Weinzierl, B., Ansmann, A., Althausen, D., Laurent, B., Petzold, A., and Schepanski, K.: Regional Saharan Dust Modelling during the SAMUM 2006 Campaign, Tellus, 61B, 307-324, 2009.

Heintzenberg, J.: The SAMUM-1 experiment over Southern Morocco: overview and introduction., Tellus, 61B, 2-11, 2009.

Helmert, J., Heinold, B., Tegen, I., Hellmuth, O., and Wendisch, M.: On the direct and semidirect effects of Saharan dust over Europe: A modeling study, J. Geophys. Res., 112, D13208, doi:10.1029/2006JD007444, 2007.

Hess, M., Koepke, P., and Schult, I.: Optical Properties of Aerosols and Clouds: The Software Package OPAC, B. Am. Meteorol. Soc., 79, 831-844, 1998.

Holben, B. N., Eck, T. F., Slutsker, I., Tanre, D., Buis, J. P., Setzer, A., Vermote, E., Reagan, J. A., Kaufman, Y. J., Nakajima, T., Lavenu, F., Jankowiak, I., and Smirnov, A.: AERONET - A federated instrument network and data archive for aerosol characterization - an overview., Remote Sens. Environ., 66, 1-16, 1998.

Hooker, S. B., Esaias, W. E., Feldman, G. C., Gregg, W. W., and McClain, C. R.: An overview of SeaWiFS and ocean colour, Tech. rep., NASA Technical Memorandum 104566; NASA Goddard Space Flight Center, Greenbelt, MD, USA, 1992.

Houghton, J. T., Ding, Y., Griggs, D. J., Noguer, M., van der Linden, P. J., and Xiaosu, D.: Climate Change 2001: The Scientific Basis: Contributions of Working Group I to the Third Assessment Report of the Intergovernmental Panel on Climate Change, Tech. rep., Cambridge University Press, 2001.

Hoyningen-Huene, W. v., Dinter, T., Kokhanovsky, A. A., Burrows, J. P., Wendisch, M., Bierwirth, E., Müller, D., and Diouri, M.: Measurement of desert dust optical characteristic at Porte au Sahara during SAMUM 2006, Tellus, 61B, 206-215, 2009.

Hsu, N. C., Herman, J. R., Torres, O., Holben, B. N., Tanre, D., Eck, T. F., Smirnov, A., Chatenet, B., and Lavenu, F.: Comparisons of the TOMS aerosol index with Sun-photometer aerosol optical thickness: Results and applications, J. Geophys. Res., 104, 6269-6279, 1999.
Hsu, N. C., Tsay, S.-C., King, M., and Herman, J. R.: Aerosol properties over bright-reflecting source regions, IEEE T. Geosci. Remote Sens., 42, 557-569, 2004.

Ignatov, A. and Gutman, G.: The derivation of the green vegetation fraction from NOAA/AVHRR data for use in numerical weather prediction models, Int. J. Remote Sens., 19, 1533-1543, doi:10.1080/014311698215333, 1998.

IPCC: Climate Change 2007: The Physical Science Basis; 4th Assessment Report, Cambridge University Press, Cambridge and New York, 2007.

Iversen, J. D. and White, B. R.: Saltation threshold on Earth, Mars and Venus, Sedimentology, 29, 111-119, 1982.

Janjic, Z., Black, T., Pyle, M., Chuang, H.-Y., Rogers, E., and DiMego, G.: High resolution applications of the WRF NMM, in: Joint Session 16, 1-21, 2005.

Janjic, Z., Gall, R., and Pyle, M. E.: Scientific Documentation for the NMM Solver, Tech. rep., NCAR, Boulder, Colorado, USA, 2010.

Janjic, Z., Janjic, T., and Vasic, R.: A Class of Conservative FourthOrder Advection Schemes and Impact of Enhanced Formal Accuracy on Extended-Range Forecasts, Mon. Weather Rev., 139, 1556-1568, 2011.

Janjic, Z. I.: The step-mountain coordinate: Physical package, Mon. Weather Rev., 118, 1429-1443, 1990.

Janjic, Z. I.: The Step-Mountain Eta Coordinate Model: Further Developments of the Convection, Viscous Sublayer, and Turbulence Closure Schemes, Mon. Weather Rev., 122, 927-945, 1994.

Janjic, Z. I.: A Nonhydrostatic Model Based on a New Approach, Meteorol. Atmos. Phys., 82, 271-285, 2003.

Janjic, Z. I. and Black, T.: From global to mesoscales with a unified model, Tech. rep., National Centers for Environmental Prediction (NCEP), 2006.

Janjic, Z. I. and Black, T.: A unified model approach from meso to global scales, Geophys. Res. Abstr., 9, SRef-ID: 16077962/gra/EGU2007-A-05 025, 2007.

Janjic, Z. I., Gerrity Jr., J. P., and Nickovic, S.: An Alternative Approach to Nonhydrostatic Modeling, Mon. Weather Rev., 129, 1164-1178, 2001.

Kallos, G., Nickovic, S., Papadopoulos, A., Jovic, D., Kakaliagou, O., Misirlis, N., Boukas, L., Mitikou, N., Sakelaridis, G., Papageorgiou, J., Anadranistakis, E., and Manousakis, M.: The Regional Weather Forecasting System SKIRON: An Overview, Proc. Symp. Reg. Weather Pred. Par. Comp. Environ., 1, 109123, 1997.

Kandler, K., Schütz, L., Deutscher, C., Hofmann, H., Jäckel, S., Knippertz, P., Lieke, K., Massling, A., Schladitz, A., Weinzierl, B., Zorn, S., Ebert, M., Jaenike, R., Petzold, A., and Weinbruch, S.: Size distribution, mass concentration, chemical and mineralogical composition and derived optical parameters of the boundary layer aerosol at Tinfou, Morocco, during SAMUM 2006, Tellus, 61B, 32-50, 2009.

Kinne, S., Lohmann, U., Feichter, J., Schulz, M., Timmreck, C., Ghan, S., Easter, R., Chin, M., Ginoux, P., Takemura, T., Tegen, I., Koch, D., Herzog, M., Penner, J., Pitari, G., Holben, B., Eck, T., Smirnov, A., Dubovik, O., Slutsker, I., Tanre, D., Torres, O., Mishchenko, M., Geogdzhayev, I., Chu, D. A., and Kaufman, Y.: Monthly averages of aerosol properties: A global comparison among models, satellite data, and AERONET ground data, J. Geophys. Res., 108, 4634, doi:10.1029/2001JD001253, 2003. 
Knippertz, P., Ansmann, A., Althausen, D., Müller, D., Tesche, M., Bierwirth, E., Dinter, T., Müller, T., Hoyningen-Huene, W. v., Schepanski, K., Wendisch, M., Heinold, B., Kandler, K., Petzold, A., Schütz, L., and Tegen, I.: Dust mobilization and transport in the northern Sahara during SAMUM 2006. A meteorological overview, Tellus, 61B, 12-31, 2009.

Koren, I. and Kaufman, Y. J.: Direct wind measurements of Saharan dust events from Terra and Aqua satellites, Geophys. Res. Lett., 31, L06122, doi:10.1029/2003GL019338, 2004.

Lacis, A. A. and Hansen, J. E.: A parameterization for the absorption of solar radiation in the Earth's atmosphere, J. Atmos. Sci., 31, 118-133, 1974.

Laurent, B., Marticorena, B., Bergametti, G., Léon, J. F., and Mahowald, N. M.: Modeling mineral dust emissions from the Sahara desert using new surface properties and soil database, J. Geophys. Res., 113, D14218, doi:10.1029/2007JD009484, 2008.

Levelt, R. F.: OMI Algorithm Theoretical Basis Document Volume 1: OMI Instrument, Level 0-1b processor, calibration and operations, Tech. rep., NASA Goddard Space Flight Center, Greenbelt, MD, 2002.

Levy, R. C., Remer, L. A., and Dubovik, O.: Global aerosol optical properties and application to Moderate Resolution Imaging Spectroradiometer aerosol retrieval over land, J. Geophys. Res., 112, D13210, doi:10.1029/2006JD007815, 2007.

Marticorena, B. and Bergametti, G.: Modeling the atmospheric dust cycle: 1 . Design of a soil-derived dust emission scheme, J. Geophys. Res., 100, 16415-16430, 1995.

Martin, R. V.: Satellite remote sensing of surface air quality, Atmos. Environ., 42, 7823-7843, 2008.

Matthias, V., Freudenthaler, V., Amodeo, A., Balin, I., Balis, D., Bösenberg, J., Chaikovsky, A., Chourdakis, G., Comeron, A., Delaval, A., De Tomasi, F., Eixmann, R., Hagard, A., Komguem, L., Kreipl, S., Matthey, R., Rizi, V., Rodrigues, J. A., Wandinger, U., and Wang, X.: Aerosol lidar intercomparison in the framework of the EARLINET project. 1. Instruments, Appl. Optics, 43, 961-976, 2004.

Menut, L., Schmechtig, C., and Marticorena, B.: Sensitivity of the Sandblasting Flux Calculations to the Soil Size Distribution Accuracy, J. Atmos. Ocean. Technol., 22, 1875-1884, 2005.

Middleton, N., Betzer, P. R., and Bull, P. A.: Long-range transport of 'giant' aeolian quartz grains: linkage with discrete sedimentary sources and implications for protective particle transfer, Marine Geol., 177, 411-417, 2001.

Miller, R. L., Perlwitz, J., and Tegen, I.: Feedback upon dust emission by dust radiative forcing through the planetary boundary layer, J. Geophys. Res., 109, D24209, doi:10.1029/2004JD004912, 2004.

Mishchenko, M. I., Travis, L. D., Kahn, R. A., and West, R. A.: Modeling phase functions for dustlike tropospheric aerosols using a shape mixture of randomly oriented polydisperse spheroids, J. Geophys. Res., 102, 16831-16847, 1997.

Mlawer, E. J., Taubman, S. J., Brown, P. D., Iacono, M. J., and Clough, S. A.: Radiative transfer for inhomogeneous atmospheres: RRTM, a validated correlated-k model for the longwave, J. Geophys. Res., 102, 16663-16682, 1997.

Morcrette, J.-J., Beljaars, A., Benedetti, A., Jones, L., and Boucher, O.: Sea-salt and dust aerosols in the ECMWF IFS model., Geophys. Res. Lett., 35, L24813, doi:10.1029/2008GL036041, 2008. Müller, D., Althausen, D., Ansmann, A., Arboledas, L., Balis,
D., Comeron, A., Freudenthaler, V., Giannakaki, E., Heese, B., Heinold, B., Iarlori, M., Knippertz, P., Lopéz Marquéz, M., Marmouri, R., Mona, L., Papayannis, A., Pappalardo, G., Pérez, C., Perrone, R.-M., Pisani, G., Rizi, V., Sicard, M., Tartufo, A., Tegen, I., and Tesche, M.: EARLINET observations of the 1422 May long-range dust transport event during SAMUM 2006: validation of results from dust transport modelling, Tellus, 61B, 325-339, 2009.

Myhre, G., Berntsen, T. K., Haywood, J. M., Sundet, J. K., Holben, B. N., Johnsrud, M., and Stordal, F.: Modeling the solar radiative impact of aerosols from biomass burning during the Southern African regional Science Initiative (SAFARI-2000) experiment, J. Geophys. Res., 108, 8501, doi:10.1029/2002JD002313, 2003.

Nickovic, S., Kallos, G., Papadopoulos, A., and Kakaliagou, O.: A model for prediction of desert dust cycle in the atmosphere, J. Geophys. Res., 106, 18113-18129, 2001.

Otto, S., Bierwith, E., Weinzierl, B., Kandler, K., Esselborn, M., Tesche, M., Schladitz, A., Wendisch, M., and Trautmann, T.: Solar radiative effects of a Saharan dust plume observed during SAMUM assuming spheroidal model particles, Tellus, 61B, 270-296, 2009.

Otto, S., Trautmann, T., and Wendisch, M.: On realistic size equivalence and shape of spheroidal Saharan mineral dust particles applied in solar and thermal radiative transfer calculations, Atmos. Chem. Phys., 11, 4469-4490, doi:10.5194/acp-11-44692011, 2011.

Papanastasiou, D. K., Poupkou, A., Katragkou, E., Amiridis, V., Melas, D., Mihalopoulos, N., Basart, S., Pérez, C., and Baldasano, J. M.: An Assessment of the Efficiency of Dust Regional Modelling to Predict Saharan Dust Transport Episodes., Adv. Meteorol., ID154368, doi:10.1155/2010/154368, 2010.

Papayannis, A., Amiridis, V., Mona, L., Tsaknakis, G., Balis, D., Bösenberg, J., Chaikovsky, A., de Tomasi, F., Grigorov, I., Mattis, I., Mitev, V., Müller, D., Nickovic, S., Pérez, C., Pietruczuk, A., Pisani, G., Ravetta, F., Rizi, V., Sicard, M., Trickl, T., Wiegner, M., and Gerding, M.: Systematic lidar observations of aerosol optical properties during Saharan dust intrusions over Europe, in the frame of EARLINET (2000-2002): Statistical analysis and results, J. Geophys. Res., 113, 1-17, D10204, doi:10.1029/2007JD009028, 2008.

Pérez, C., Nickovic, S., Baldasano, J. M., Sicard, M., Rocadenbosch, F., and Cachorro, V. E.: A long Saharan dust event over the western Mediterranean: Lidar, Sun photometer observations, and regional dust modeling, J. Geophys. Res., 111, D15214, doi:10.1029/2005JD006579, 2006a.

Pérez, C., Nickovic, S., Pejanovic, G., Baldasano, J. M., and Özsoy, E.: Interactive dust-radiation modeling: A step to improve weather forecasts, J. Geophys. Res., 111, D16206, doi:10.1029/2005JD006717, 2006b.

Pérez, C., Jiménez-Guerrero, P., Jorba, O., Baldasano, J., Cuevas, E., Nickovic, S., and Querol, X.: Long-term simulations (19582006) of Saharan dust over the Mediterranean and the Eastern North Atlantic with the DREAM regional dust model., in: XXIV International Union of Geodesy and Geophysics (IUGG) General Assembly, Perugia, Italy, 2-13 July., 2007.

Pérez, C., Haustein, K., Janjic, Z., Jorba, O., Huneeus, N., Baldasano, J. M., Black, T., Basart, S., Nickovic, S., Miller, R. L., Perlwitz, J. P., Schulz, M., and Thomson, M.: Atmospheric dust modeling from meso to global scales with the online 
NMMB/BSC-Dust model: 1. Model description, annual simulations and evaluation, Atmos. Chem. Phys., 11, 13001-13027, doi:10.5194/acp-11-13001-2011, 2011.

Prospero, J. M., Ginoux, P., Torres, O., Nicholson, S. E., and Gill, T. E.: Environmental characterization of global sources of atmospheric soil dust identified with the NIMBUS 7 total ozone mapping spectrometer (TOMS) absorbing aerosol product, Rev. Geophys., 40, 1002, doi:10.1029/2000RG000095, 2002.

Remer, L. A., Kaufman, Y. J., Tanré, D., Mattoo, S., Chu, D. A., Martins, J. V., Li, R. R., Ichoku, C., Levy, R. C., Kleidman, R. G., Eck, T. F., Vermote, E., and Holben, B. N.: The MODIS aerosol algorithm, products and validation, J. Atmos. Sci., 62, 947-973, 2005.

Rodell, M., Houser, P. R., Jambor, U., Gottschalck, J., Mitchell, K., Meng, C. J., Arsenault, K., Cosgrove, B., Radakovich, J., Bosilovich, M., Entin, J. K., Walker, J. P., Lohmann, D., and Toll, D.: The Global Land Data Assimilation System, B. Am. Meteorol. Soc., 85, 381-394, 2004.

Schepanski, K., Tegen, I., Laurent, B., Heinold, B., and Macke, A.: A new Saharan dust source activation frequency map derived from MSG-SEVIRI IR-channels., Geophys. Res. Lett., 34, L18803, doi:10.1029/2007GL030168, 2007.

Schepanski, K., Tegen, I., Todd, M. C., Heinold, B., Bönisch, G., Laurent, B., and Macke, A.: Meteorological processes forcing Saharan dust emission inferred from MSG-SEVIRI observations of subdaily dust source activation and numerical models, J. Geophys. Res., 114, D10201, doi:10.1029/2008JD010325, 2009.

Schladitz, A., Müller, T., Kaaden, N., Massling, A., Kandler, K., Ebert, M., Weinbruch, S., Deutscher, C., and Wiedensohler, A.: In situ measurements of optical properties at Tinfou (Morocco) during the Saharan Mineral Dust Experiment SAMUM 2006, Tellus, 61B, 64-78, 2009.

Schmetz, J., Pili, P., Tjemkes, S., Just, D., Kerkmann, J., Rota, S., and Ratier, A.: An introduction to Meteosat Second Generation (MSG), B. Am. Meteorol. Soc., 83, 977-992, 2002.

Schütz, L., Jaenicke, R., and Pietrek, H.: Saharan dust transport over the North Atlantic Ocean., Geol. Soc. Am., Special Papers, 186, 87-100, 1981.

Slinn, W.: Predictions for particle deposition to vegetative surfaces, Atmos. Environ., 16, 1785-1794, 1982.

Sokolik, I. N. and Toon, O. B.: Direct radiative forcing by anthropogenic airborne mineral aerosols, Nature, 381, 681-683, 1996.

Tanaka, T. Y. and Chiba, M.: Global Simulation of Dust Aerosol with a Chemical Transport Model, MASINGAR, J. Meteorol. Soc. Jpn., 83A, 255-278, 2005.

Tegen, I.: Modeling the mineral dust aerosol cycle in the climate system., Quat. Sci. Rev., 22, 1821-1834, 2003.

Tegen, I., Harrison, S. P., Kohfeld, K., Prentice, I. C., Coe, M., and Heimann, M.: Impact of vegetation and preferential source areas on global dust aerosol: Results from a model study, J. Geophys. Res., 107, 4576, doi:10.1029/2001JD000963, 2002.

Tegen, I., Heinold, B., Todd, M., Helmert, J., Washington, R., and Dubovik, O.: Modelling soil dust aerosol in the Bodélé depression during the BoDEx campaign, Atmos. Chem. Phys., 6, 43454359, doi:10.5194/acp-6-4345-2006, 2006.

Tesche, M., Ansmann, A., Müller, D., Althausen, D., Mattis, I., Heese, B., Freudenthaler, V., Wiegner, M., Esselborn, M., Pisani, G., and Knippertz, P.: Vertical profiling of Saharan dust with Raman lidars and airborne HSRL in southern Morocco during
SAMUM., Tellus, 61B, 144-164, 2009.

Todd, M. C., Washington, R., Martins, J. V., Dubovik, O., Lizcano, G., M'Bainayel, S., and Engelstaedter, S.: Mineral dust emission from the Bodélé Depression, northern Chad, during BoDEx 2005, J. Geophys. Res., 112, D06207, doi:10.1029/2006JD007170, 2007.

Todd, M. C., Bou Karam, D., Cavazos, C., Bouet, C., Heinold, B., Baldasano, J. M., Cautenet, G., Koren, I., Pérez, C., Solmon, F., Tegen, I., Tulet, P., Washington, R., and Zakey, A.: Quantifying uncertainty in estimates of mineral dust flux: An intercomparison of model performance over the Bodélé Depression, northern Chad, J. Geophys. Res., 113, D24107, doi:10.1029/2008JD010476, 2008a.

Todd, M. C., Washington, R., Raghavan, S., Lizcano, G., and Knippertz, P.: Regional model simulations of the Bodélé LowLevel Jet of Northern Chad during the Bodélé Dust Experiment (BoDEx 2005), J. Climate, 21, 995-1013, 2008b.

Torres, O., Tanskanen, T., Veihelmann, B., Ahn, C., Braak, R., Bhartia, P. K., Veefkind, P., and Levelt, P.: Aerosols and surface UV products from Ozone Monitoring Instrument observations: An overview, J. Geophys. Res., 112, D24S47, doi:10.1029/2007JD008809, 2007.

Washington, R. and Todd, M. C.: Atmospheric controls on mineral dust emission from the Bodélé Depression, Chad: The role of the low level jet, Geophys. Res. Lett., 32, L17701, doi:10.1029/2005GL023597, 2005.

Washington, R., Todd, M. C., Engelstaedter, S., M'bainayel, S., and Mitchell, F.: Dust and the low-level circulation over the Bodélé Depression, Chad: Observations from BoDEx 2005, J. Geophys. Res., 111, D03201, doi:10.1029/2005JD006502, 2006 .

Washington, R., Todd, M. C., Lizcano, G., Tegen, I., Flamant, C., Koren, I., Ginoux, P., Engelstaedter, S., Bristow, C. S., Zender, C. S., Goudie, A. S., Warren, A., and Prospero, J. M.: Links between topography, wind, deflation, lakes and dust: The case of the Bodélé Depression, Chad, Geophys. Res. Lett., 33, L09401, doi:10.1029/2006GL025827, 2006b.

Washington, R. W., Todd, M. C., Middleton, N., and Goudie, A. S.: Dust-storm source areas determined by the total ozone monitoring spectrometer and surface observations, Ann. Assoc. Am. Geogr., 93, 297-313, 2003.

Weinzierl, B., Petzold, A., Esselborn, M., Wirth, M., Rasp, K., Kandler, K., Schütz, L., Koepke, P., and Fiebig, M.: Airborne measurements of dust layer properties, particle size distribution and mixing state of Saharan dust during SAMUM 2006, Tellus, 61B, 96-117, 2009.

White, B. R.: Soil transport by winds on Mars, J. Geophys. Res., 84, 4643-4651, 1979.

Yin, D., Nickovic, S., Barbaris, B., Chandy, B., and Sprigg, W.: Modeling wind-blown desert dust in the southwestern United States for public health warning: A case study, Atmos. Environ., 39, 6243-625, 2005.

Zender, C. S., Bian, H., and Newman, D.: Mineral Dust Entrainment and Deposition (DEAD) model: Description and 1990s dust climatology, J. Geophys. Res., 108, 4416, doi:10.1029/2002JD002775, 2003a.

Zender, C. S., Newman, D., and Torres, O.: Spatial heterogeneity in aeolian erodibility: Uniform, topographic, geomorphic, and hydrologic hypotheses, J. Geophys. Res., 108, 4543, doi:10.1029/2002JD003039, 2003b. 
Zender, C. S., Miller, R. L., and Tegen, I.: Quantifying Mineral Dust Mass Budgets: Terminology, Constraints, and Current Estimates., Electronic Supplement (EOS), 85, 509-512, 2004.

Zhang, L., Gong, S., Padro, J., and Barrie, L.: A size-segregated particle dry deposition scheme for an atmospheric aerosol module, Atmos. Environ., 35, 549-560, 2001.
Zhao, C., Liu, X., Leung, L. R., Johnson, B., McFarlane, S. A., Gustafson Jr., W. I., Fast, J. D., and Easter, R.: The spatial distribution of mineral dust and its shortwave radiative forcing over North Africa: modeling sensitivities to dust emissions and aerosol size treatments, Atmos. Chem. Phys., 10, 8821-8838, doi:10.5194/acp-10-8821-2010, 2010. 